\title{
Paleo-environmental gateways in the eastern Canadian arctic - Recent isotope hydrology and diatom oxygen isotopes from Nettilling Lake, Baffin Island, Canada
}

\author{
B. Chapligin ${ }^{\text {a, * }}$, B. Narancic ${ }^{\text {b }}$, H. Meyer ${ }^{\text {a }}$, R. Pienitz ${ }^{\text {b }}$ \\ a Alfred Wegener Institute Helmholtz Centre for Polar and Marine Research, Research Unit Potsdam, Telegrafenberg A43, D-14473 Potsdam, Germany \\ ${ }^{\mathrm{b}}$ Laboratoire de Paléoécologie Aquatique, Centre d'études nordiques \& Département de géographie, Université Laval, QC, G1V 0A6, Canada
}

\section{A R T I C L E I N F O}

\section{Article history:}

Received 7 July 2015

Received in revised form

18 February 2016

Accepted 22 March 2016

Available online $\mathrm{xxx}$

\section{Keywords:}

Biogenic silica

Climate-reconstruction

Arctic

Post-glacial

Marine-lacustrine transition

\begin{abstract}
A B S T R A C T
Nettilling Lake is located on Baffin Island, Nunavut, Canada between the areas of past warming (Canadian High Arctic to the North) and climatic stability (Northern Quebec and Labrador region to the South). Despite being the largest lake in the Nunavut region with a postglacial marine to lacustrine transition history only a few paleo-environmental investigations were completed in this area. The oxygen isotope composition of diatoms $\left(\delta^{18} \mathrm{O}_{\text {diatom }}\right)$ can provide valuable insights into paleo-environmental conditions. Here, the recent (isotope) hydrology and hydrochemical data from the lake are presented to facilitate the interpretation of a $\delta^{18} \mathrm{O}_{\text {diatom }}$ record from an $82 \mathrm{~cm}$ sediment core $(\mathrm{Ni}-2 \mathrm{~B})$.

The well-mixed lake $\left(\delta^{18} \mathrm{O}_{\text {water }}=-17.4 \%\right.$ ) is influenced by a heavier (less negative) isotope composition $(-18.80 \%$ ) from Amadjuak River draining Amadjuak Lake to the South and water of lighter (more negative) isotopic composition $(-16.4 \%$ ) from the Isurtuq River originating from Penny Ice Cap in the North-East. From the $\delta^{18} \mathrm{O}_{\text {water }}$ and $\delta^{18} \mathrm{O}_{\text {diatom }}$ of the topmost sample of core Ni-2B a $\Delta^{18} \mathrm{O}_{\text {silica-water }}$ of 1000 $\ln \alpha_{\text {(silica-water })}=40.2 \%$ for sub-recent diatoms of Nettilling Lake was calculated matching the known water-silica fractionation for fossil sediments well and thereby showing the general applicability of this proxy for paleo-reconstructions in this region.

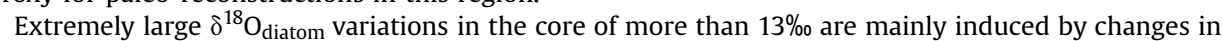
the isotopic composition of the lake water due to a shift from glaciomarine $\left(\delta^{18} \mathrm{O}_{\text {diatom }}=+34.6 \%\right.$ ) through brackish $(+23.4$ to $+27.2 \%)$ towards lacustrine $(+21.5 \%$ ) conditions (transition zones glaciomarine to brackish at $69 \mathrm{~cm} / 7300 \mathrm{yr}$ cal. BP and brackish to lacustrine at $35 \mathrm{~cm} / 6000 \mathrm{yr}$ cal. BP) associated with a shift in the degree of salinity. Our study provides the first evidence that paleo-salinity can be reconstructed by $\delta^{18} \mathrm{O}_{\text {diatom. }}$. Additionally, for the lacustrine section it could be demonstrated that $\delta^{18} \mathrm{O}_{\text {diatom }}$ may serve as a proxy for past air temperature within the same core recording a late Holocene cooling of about $4{ }^{\circ} \mathrm{C}$ being consistent with other published values for the greater Baffin region.
\end{abstract}

(c) 2016 Elsevier Ltd. All rights reserved.

\section{Introduction}

Despite being the largest lake in the Canadian Arctic Archipelago, little is known about Nettilling Lake. The lake is located on south-central Baffin Island - an area between regions that experienced contrasting Holocene climate regimes since the last deglaciation: Extreme warming in the Canadian High Arctic to the North versus climatic stability of the Foxe Basin, Northern Québec and the Labrador region to the South (Jacobs et al., 1997; Pienitz et al., 2004;

\footnotetext{
* Corresponding author.

E-mail address: bernhard.chapligin@awi.de (B. Chapligin).
}

Smol et al., 2005).

The first field observations around Nettilling Lake were completed by Oliver (1964) in 1956. Jacobs and Grondin (1988) and Jacobs et al. (1997) focused on recent climate and vegetation characteristics of the southernmost part of the lake revealing relatively mild summers and cold winters. Although some Holocene paleoclimate reconstructions exist from Baffin Island (Axford et al., 2009; Briner et al., 2006; Joynt and Wolfe, 2001; Thomas et al., 2011, 2008) records from the southwestern part of the island are sparse but needed to refine the postglacial environmental history and past gateways in this remote region.

To reconstruct paleo-environmental conditions the isotope 
analysis of biogenic silica has become a useful proxy. Oxygen isotopes of biogenic silica are used to reconstruct past air temperatures (Chapligin et al., 2012b; Shemesh et al., 2001), paleohydrological settings (Mackay et al., 2008), paleo sea-surface temperatures (Labeyrie, 1974; Shemesh et al., 1992) or changes in airmass sources (Shemesh et al., 2001). Overviews of the applications of the isotope analysis of biogenic silica are provided in Leng and Barker (2006) and Swann and Leng (2009).

However, before using this proxy a careful study of the recent isotope hydrology of the lake has to be performed (lake water, precipitation, inflow, outflow). These investigations were combined with a multi-proxy paleolimnological study of three sedimentary records retrieved from Nettilling Lake (Narancic et al., this issue). Within this project, our study aims (1) to assess the recent isotope hydrology and hydrochemistry of Nettilling Lake for delivering essential background information for palaeo-environmental interpretation, (2) to compare $\delta^{18} \mathrm{O}$ values of sub-recent diatom samples to the oxygen isotope composition of the lake, and (3) to investigate the possibility of using $\delta^{18} \mathrm{O}$ measurements in biogenic silica for recording changes in paleosalinity as the Nettilling Lake basin experienced a glaciomarine-lacustrine transition in the midHolocene. One additional goal was to observe whether $\delta^{18} \mathrm{O}$ values of diatom silica could act as a proxy for two different parameters (hydrological changes, air temperature) in different sections of the same core.

\section{Material and methods}

\subsection{Study site}

Nettilling Lake is the largest lake in the Canadian Arctic Archipelago and the sixth largest lake in Canada It is located on Baffin Island extending south and north of the polar circle (lake extension: $65^{\circ} 53.767^{\prime} \mathrm{N} ; 71^{\circ} 17.865^{\prime} \mathrm{W}$ to $66^{\circ} 59.569^{\prime} \mathrm{N} ; 7^{\circ} 07.204^{\prime} \mathrm{W}$; Fig. 1 ; Oliver, 1964). The lake has two main inflows: (1) The Amadjuak River entering from the South (into Burwash Bay) which drains from Amadjuak Lake (64. $55^{\prime} \mathrm{N}, 71^{\circ} 09^{\prime} \mathrm{W} ; 113 \mathrm{~m}$ asl.) and Mingo Lakes and (2) Isurtuq River entering the North-East originating from Penny Ice Cap $\left(67^{\circ} 15^{\prime} \mathrm{N}, 65^{\circ} 45^{\prime} \mathrm{W} ; 1900 \mathrm{~m}\right.$ asl.). The Penny Ice Cap is a remnant of the Laurentide Ice Sheet, which was once connected to the Foxe Dome (Fisher et al., 1998). The Koukdjuak River is the lake's main outflow in the West draining into Foxe Basin. The eastern part of the lake is shallow with several islands (mean depth 10-25 $\mathrm{m}$ ) whereas the western part has a deeper basin with water depths up to ca. $65 \mathrm{~m}$ (mostly 40-60 m; Oliver, 1964). Geologically the region is characterised by Precambrian rocks in the North-East and Ordovician carbonate-rich sedimentary rocks to the West. The ice break-up starts between the middle and the end of July and the lake becomes free of ice between the end of July and the first week of August (Oliver, 1964 and pers. comm. Pat Rakowski, Canadian Wildlife Service; based on 5 yrs of observations in the camp). Water temperatures remain below $4{ }^{\circ} \mathrm{C}$ in summer in the deeper western part of the lake basin while rising above $4{ }^{\circ} \mathrm{C}$ (ca. $7-8^{\circ} \mathrm{C}$ ) in the island-rich and shallower eastern part (Oliver, 1964). In August 2014, all water profiles taken revealed a wellmixed lake and the absence of a thermocline. A Secchi disc depth of mostly greater than $10 \mathrm{~m}$ was observed (Oliver, 1964).

\subsection{Sample material and age model}

Lake water samples were taken at different water depths with a UWITEC water sampling device (UWITEC Corp., Austria), in most cases (apart from the water samples taken at the sediment cores' sites from the zodiac) directly from the helicopter in approx. 1-2 m water depth. Subsamples were taken from the water sampling device in the boat or helicopter for isotope and hydrochemistry analyses.

As the Global Network of Isotopes in Precipitation (GNIP) has only 3 stations in the Nunavut region and none in the South or Center of Baffin Island, there was a need for year-round precipitation sampling for isotope analysis which was performed at the Nunavut Research Institute (NRI) in Iqaluit since Sept 2013. Thirty samples in the year until Sept 2014 were taken for isotope analysis.

Climate (air temperature, ...) data was recorded by a meteorological station with year-round automatic data acquisition at Nettilling Lake since 2010 which was set up by the Centre for Northern Studies at Laval University (Québec, Canada). Other climate data for Iqaluit was taken from http://www.iqaluit.climatemps.com/ and http://climate.weather.gc.ca/climateData/). Modelled isotope values were retrieved from the Online Isotopes in Precipitation Calculator, version 2.2. from http://www.waterisotopes.org (Bowen, 2015, based on Bowen and Revenaugh, 2003).

The core Ni2-B $(82 \mathrm{~cm})$ was taken from the north-eastern part of the lake (Fig. 1) at $14 \mathrm{~m}$ water depth using a $7 \mathrm{~cm}$-diameter handheld percussion corer (Aquatic Research Instruments). At each coring site, the water depth was measured with a portable echosounder sonar (Lowrance).

A composite age-depth model was developed using four cores from the lake (Fig. 2, see details of the complete age model in Narancic et al., this issue). As these cores contain three recognizably concordant lithostratigraphic zones, the overlap of these zones was used to establish the composite core depth. The age-depth core chronology is based on 25 accelerator mass spectrometry (AMS) ${ }^{14} \mathrm{C}$ dates. For the three stratigraphic zones the following corresponding time intervals were defined: (1) the glaciomarine phase (ca. 8300 and $7300 \mathrm{yr}$ cal. BP; 69-82 cm core depth), (2) the brackish water (transitional) phase and the beginning of basin isolation from marine influence (ca. 7300 and $6000 \mathrm{yr}$ cal. BP; 35-69 cm depth) and (3) the lacustrine phase that marks the complete isolation of the basin from glaciomarine waters and the establishment of the present-day lake conditions (at ca. $6000 \mathrm{yr}$ cal. BP, $35 \mathrm{~cm}$ depth). Since then, the lacustrine sedimentation (of the upper $0-35 \mathrm{~cm}$ of the core) occurred continuously to the present at very low and likely decreasing rates with a surface sample age of ca. 300 BP as suggested by paleomagnetic dating (Narancic and St-Onge, pers. comm).

The core was sampled at $0.5 \mathrm{~cm}$ intervals for isotope analysis. Pure biogenic silica samples are required to analyse for the oxygen isotope composition in diatoms (Leng and Sloane, 2008). Therefore, various chemical and physical preparation steps were performed to separate diatom frustules from sediment material (Morley et al. 2004; Chapligin et al., 2012a). The freeze-dried samples were treated with $\mathrm{H}_{2} \mathrm{O}_{2}(32 \%)$ and $\mathrm{HCl}(10 \%)$ to remove organic matter and carbonates and wet sieved into $<10 \mu \mathrm{m}$ and $>10 \mu \mathrm{m}$ fractions from which the $<10 \mu \mathrm{m}$ fraction was further used as the final amount of pure diatom material was sufficient for isotope analysis. Four multiple heavy liquid separation (HLS) steps with varying densities (from 2.25 to $2.15 \mathrm{~g} / \mathrm{cm}^{3}$ ) were then applied using a sodium polytungstate (SPT) solution before being exposed to a mixture of $\mathrm{HClO}_{4}(65 \%)$ and $\mathrm{HNO}_{3}$ (65\%) for removing any remaining micro-organics.

\subsection{Hydrochemistry}

Water samples for major ion analyses were filtered through cellulose-acetate filters (Whatman ${ }^{\mathrm{TM}} \mathrm{CA}$; pore size $0.4 \mu \mathrm{m}$ ). Then, samples for the cation analyses were acidified with $\mathrm{HNO}_{3}$ suprapure (65\%) to prevent microbial conversion processes and adsorptive accretion. The cation content was analysed by inductively coupled plasma-optical emission spectrometry (ICP-OES, Perkin- 


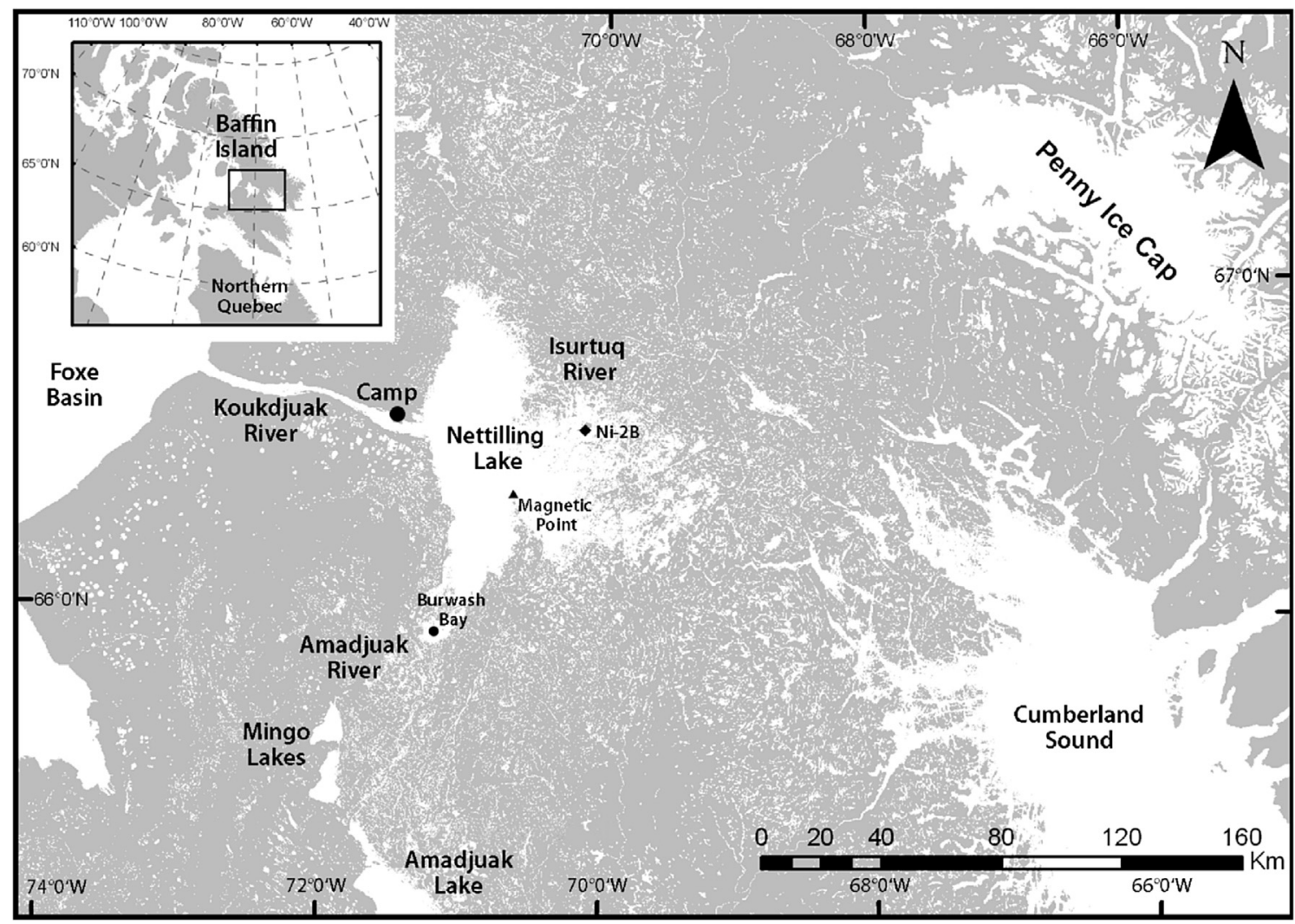

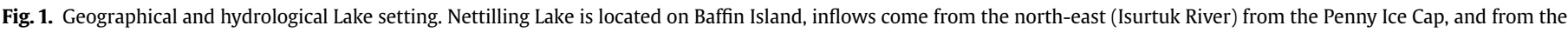
south (Amadjuak River) from Amadjuak and Mingo Lakes into Burwash Bay. One outflow on the western side (Koukudjuak River) drains into Foxe Basin.

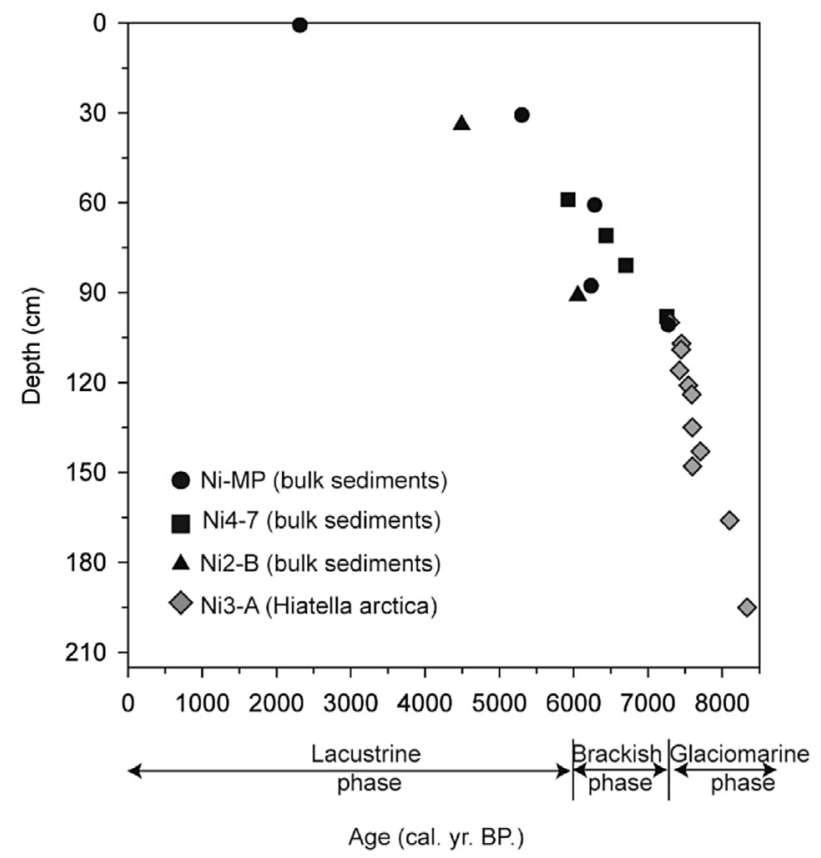

Fig. 2. Composite age-depth model using four cores from Nettilling Lake (taken from Narancic et al., this issue). The lacustrine sedimentation occurred continuously with a surface sample age of ca. $300 \mathrm{BP}$ based on paleomagnetic dating (Narancic and St. Onge pers. comm.).

Elmer Optima $3000 \mathrm{XL}$ ), while the anion content was determined by ion chromatography (IC, Dionex DX-320). Hydrogen carbonate concentrations were measured by titration with $0.01 \mathrm{M} \mathrm{HCl}$ using an automatic titrator (Metrohm 794 Basic Titrino). Dissolved oxygen [\%], the electric conductivity $[\mu \mathrm{S} / \mathrm{cm}], \mathrm{pH}$ and water temperature were measured directly in the water using a YSI meter (600 QS Multi Parameter Water Quality Monitor).

\subsection{Isotope analyses}

To measure the oxygen isotope composition from biogenic silica, the purified material was heated up to $1100{ }^{\circ} \mathrm{C}$ by ramp degassing under an Argon flow by inert Gas Flow Dehydration (iGFD) to remove any exchangeable oxygen (Chapligin et al., 2010). Then, the oxygen isotope composition was analysed with a semi-automated laser-fluorination line as published by Chapligin et al. (2010) following the principle of Sharp (1990). $\mathrm{BrF}_{5}$ was used as reagent to liberate the oxygen as stated in Clayton and Mayeda (1963), which was then directly measured against an oxygen reference sample of known isotopic composition. The working standard BFC, calibrated within an inter-laboratory comparison (Chapligin et al., 2011 ) was used. With a $\delta^{18} \mathrm{O}$ value of $+29.0 \pm 0.3 \%$ o $(1 \sigma)$ BFC is the closest diatom working standard to the samples from Nettilling Lake. The measured isotopic composition for BFC within this series was $28.8 \pm 0.04 \%$, $\mathrm{n}=5$.

The measured oxygen isotope composition $\left(\delta^{18} \mathrm{O}_{\text {measured }}\right)$ was corrected (to $\delta^{18} \mathrm{O}_{\text {corr }}$ ) using geochemical mass-balancing (Swann and Leng, 2009; Chapligin, 2012a).

$$
\delta^{18} \mathrm{O}_{\text {corr }}=\left(\delta^{18} \mathrm{O}_{\text {measured }}-\% \text { cont. } * \delta^{18} \mathrm{O}_{\text {cont. }}\right) / \% \text { purity }
$$

where the percentage of purity was $100 \%$ subtracted by the percentage of remaining contamination (\%cont.). The \%cont. was 
calculated by dividing the sample percentage of $\mathrm{Al}_{2} \mathrm{O}_{3}$ by the $\mathrm{Al}_{2} \mathrm{O}_{3}$ percentage from a $100 \%$ contamination end member according to Brewer et al. (2008), Swann and Leng (2009) and Mackay et al. (2011). The $\mathrm{Al}_{2} \mathrm{O}_{3}$ percentage for each sample was analysed by Energy-Dispersive X-ray Spectroscopy (EDS) using the scanningelectron microscope (SEM) (3-5 repetitions, diameter of excitedarea size: ca. $200 \mu \mathrm{m})$. The \%cont. and $\delta^{18} \mathrm{O}_{\text {cont. }}$ end-members were determined from the heavy fractions of five samples taken after the first heavy liquid separation containing no diatoms (verified using SEM) (Chapligin et al., 2012a). This resulted in a mean $\mathrm{Al}_{2} \mathrm{O}_{3}=20.7 \pm 1.7 \%$ and $\delta^{18} \mathrm{O}_{\text {cont. }}=12.3 \pm 0.8 \%$.

The oxygen isotope composition of water was analysed using the common equilibration technique with a Finnigan MAT Delta-S mass spectrometer equipped with two equilibration units for the online determination of $\delta^{18} \mathrm{O}$ and $\delta \mathrm{D}$ values (Meyer et al., 2000). The final $\delta^{18} \mathrm{O}$ values for silica as well as for $\delta^{18} \mathrm{O}$ and $\delta \mathrm{D}$ for water were calculated relative to Vienna Standard Mean Ocean Water (VSMOW) (Gonfiantini, 1978) and showed a standard deviation of $0.2-0.3 \%$ o $(1 \sigma)$ for biogenic silica and $<0.10 \%$ and $<0.8 \%$ o $(1 \sigma)$ for water, respectively.

\section{Results}

\subsection{Hydrochemistry}

Lake water profiles for $\mathrm{pH}, \mathrm{DO}[\%]$, conductivity $[\mu \mathrm{S} / \mathrm{cm}]$, water temperature $\left[{ }^{\circ} \mathrm{C}\right]$ and oxygen isotopes [\%o vs. VSMOW] were taken at three different sites (Fig. 1 map, Fig. 3 profiles): (1) Burwash Bay in the south of the lake close to the Amadjuak River inflow, (2) Magnetic Point in the center of the lake, and (3) Ni-2B, the coring site in the north-eastern part of the lake. None of these parameters showed a significant gradient down the water column. The electrical conductivity is generally low in the complete lake $(<90 \mu \mathrm{S} /$ $\mathrm{cm}$ ). The highest conductivity was measured at Burwash Bay $(88 \mu \mathrm{S} / \mathrm{cm})$, at Magnetic Point a conductivity of $31 \mu \mathrm{S} / \mathrm{cm}$ was detected whereas Ni-2B showed the lowest conductivity with ca. $13 \mu \mathrm{S} / \mathrm{cm}$. The highest temperature was recorded for Burwash Bay $\left(9.3-9.5^{\circ} \mathrm{C}\right)$, the lowest for Magnetic Point $\left(3.2-3.7^{\circ} \mathrm{C}\right)$. For the $\mathrm{Ni}$ $2 \mathrm{~B}$ site a temperature between 7.2 and $7.5^{\circ} \mathrm{C}$ was measured. The $\mathrm{pH}$ at Ni-2B was slightly lower (5.6-5.9) than at Magnetic Point (6.0-6.1). The dissolved oxygen showed an oxygen saturation of 88-92\% (Burwash Bay and Ni-2B).

Additionally, 22 water samples from the lake and the rivers (Fig. 4, numbered orange boxes) taken at approx. 1-2 $\mathrm{m}$ water depth were analysed for their hydrochemistry (Table 1$)$. The results can be clustered into five zones: (1) The Isurtuq River inflow from the North-East, (2) the North-East of the lake, (3) the lake center, (4) the southern part of the lake including Amadjuak River, and (5) the outflow of Koukdjuak River. Focusing on the main components $\mathrm{Ca}^{2+}$ and $\mathrm{HCO}_{3}^{-}$being representative for the concentrations of other major anions/cations, the Isurtuq River generally showed extremely low ion concentrations (Samples IDs 11, 13, 14: mean $\mathrm{c}\left(\mathrm{Ca}^{2+}\right)=0.5 \pm 0.1 \mathrm{mg} / \mathrm{L}$; mean $\left.\mathrm{c}\left(\mathrm{HCO}_{3}^{-}\right)=1.3 \pm 0.3 \mathrm{mg} / \mathrm{L}\right)$ whereas the southern inflow of Amadjuak River and Burwash Bay area showed a much higher ion concentration (Samples IDs 24, 29, BB: mean $\mathrm{c}\left(\mathrm{Ca}^{2+}\right)=13.0 \pm 1.0 \mathrm{mg} / \mathrm{L} ;$ mean $\left.\mathrm{c}\left(\mathrm{HCO}_{3}^{-}\right)=31.1 \pm 2.9 \mathrm{mg} / \mathrm{L}\right)$. The samples being closer to the center of the lake show intermediate concentrations (Samples IDs 5, 8, 9, MP: mean $\mathrm{c}\left(\mathrm{Ca}^{2+}\right)=9.7 \pm 1.0 \mathrm{mg} / \mathrm{L}$; mean $\left.\mathrm{c}\left(\mathrm{HCO}_{3}^{-}\right)=24.2 \pm 4.6 \mathrm{mg} / \mathrm{L}\right)$ whereas samples from the north-eastern part of the lake showed ion concentrations closer to the ones from Isurtuq River (Samples IDs 1, 2, 3, 4, 10: mean $\mathrm{c}\left(\mathrm{Ca}^{2+}\right)=4.5 \pm 0.6 \mathrm{mg} / \mathrm{L} ;$ mean $\left.\mathrm{c}\left(\mathrm{HCO}_{3}^{-}\right)=12.7 \pm 2.1 \mathrm{mg} / \mathrm{L}\right)$. For Koukdjuak River similar concentrations were detected than for the southern part of the lake (Samples IDs 16, 18, 20, 22: mean $\mathrm{c}\left(\mathrm{Ca}^{2+}\right)=12.3 \pm 0.3 \mathrm{mg} / \mathrm{L}$; mean $\left.\mathrm{c}\left(\mathrm{HCO}_{3}^{-}\right)=34.2 \pm 3.6 \mathrm{mg} / \mathrm{L}\right)$.

\subsection{Isotope hydrology}

Thirty precipitation samples at Iqaluit (ca. $300 \mathrm{~km}$ south of Nettilling Lake) were taken from the beginning of September 2013 to the end of August 2014 and were analysed for $\delta^{18} \mathrm{O}$ and $\delta \mathrm{D}$ (Fig. 5c, d, e, solid lines). The maximum $\delta^{18} \mathrm{O}$ value was $-10.75 \%$ (recorded on Aug 20th, 2014; $\delta \mathrm{D}=-80.4 \%$ ), the minimum $\delta^{18} \mathrm{O}$ value was $-35.62 \%$ ( Jan 31 st, $2014 ; \delta \mathrm{D}=-278.9 \%$ ). One value (Jan $1 \mathrm{st}, 2014)$ was excluded from interpretation due to an extremely low d excess (-22.5) indicating that the sample was likely exposed to air for a longer time interval. Mean monthly values were calculated (grey circles). Whenever no values were available (December 2013, May and July 2014) the mean monthly values from the month before and after were used and the average calculated. By using the mean monthly precipitation (Fig. 5a; grey: monthly average precipitation, taken from http://www.iqaluit.climatemps.com/; black: precipitation in the investigated year Sept 2013-2014 taken from http://climate.weather.gc.ca/climateData/) the mean annual oxygen isotope signal at Iqaluit from Sept 2013-2014 was calculated and yielded a $\delta^{18} \mathrm{O}$ value of $-19.3 \%$. For comparative reasons Fig. $5 \mathrm{c}$ shows the calculated mean monthly isotope values from

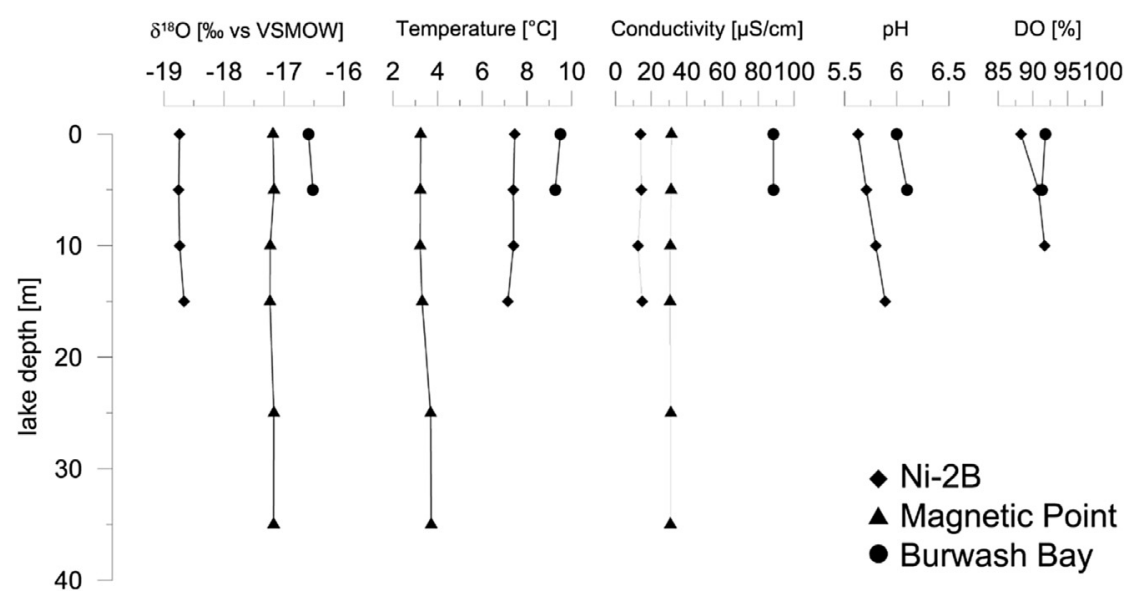

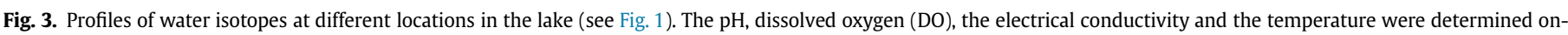
site, the oxygen isotope composition analysed in the laboratory. 


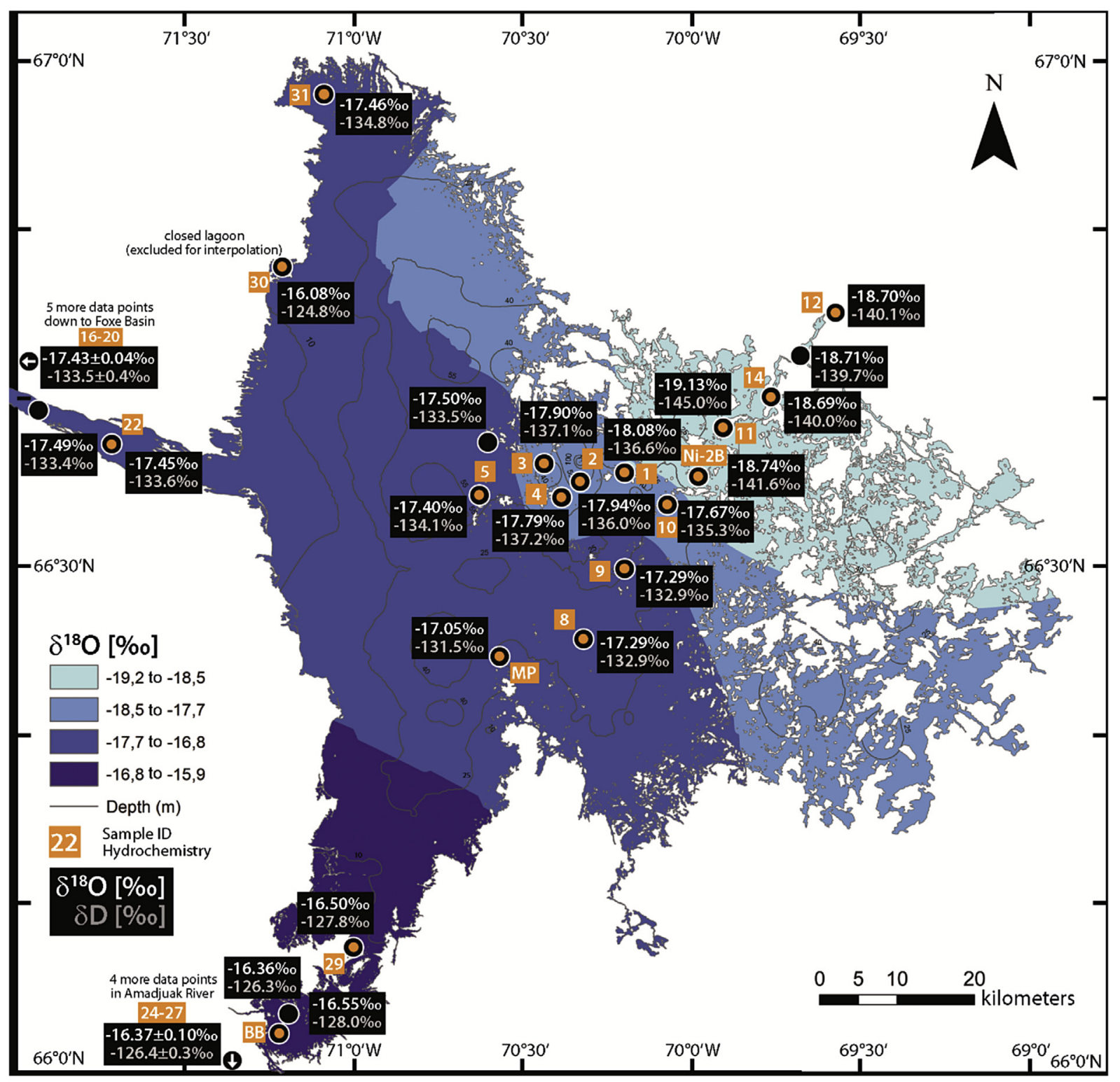



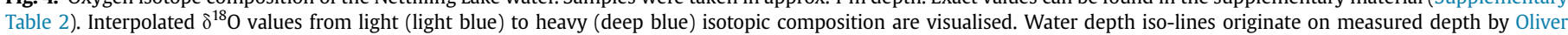
(1964) and are interpolated by Narancic et al. (this issue).

precipitation for Iqaluit (grey diamonds) and Nettilling Lake (black diamonds) following Bowen (2015, The Online Isotopes in Precipitation Calculator, version 2.2. http://www.waterisotopes.org; based on Bowen and Revenaugh, 2003). The calculated mean annual isotope values for Iqaluit were $\delta^{18} \mathrm{O}=-18.6 \%$ o $\left(\delta \mathrm{D}=-144 \%\right.$ ) and $\delta^{18} \mathrm{O}=-20.8 \%$ o $(\delta \mathrm{D}=-158 \%$ ) for Nettilling Lake, respectively.

Precipitation isotope data from Nettilling Lake (Fig. 5c, d; black circles) that was collected during the time of the expedition between 16 and 22 of August 2014 showed variations in $\delta^{18} \mathrm{O}$ value between $-11.4 \%$ and $-16.4 \%$ and for $\delta \mathrm{D}$ between $-80.3 \%$ and $-124.3 \%$. Precipitation samples taken during the 2013 expedition from Aug 3 to Aug 16 showed $\delta^{18} \mathrm{O}$ values varying between $-12.3 \%$ and $13.1 \%$ ( $\delta \mathrm{D}$ between $-100.5 \%$ and $-108.3 \%$ ).

Mean daily (solid line) and monthly (single symbols) temperature variations (Fig. 5b) at Nettilling Lake (black, own data from the meteorology station) follow the data from Iqaluit (grey, taken from
http://climate.weather.gc.ca/climateData/) closely with a mean annual temperature difference of $-2.4{ }^{\circ} \mathrm{C}$. The mean annual temperature calculated from mean daily temperatures (Sept 2013-2014) was $-11.4{ }^{\circ} \mathrm{C}$ at Nettilling Lake and $-9.1{ }^{\circ} \mathrm{C}$ at Iqaluit with minima of $-35.6{ }^{\circ} \mathrm{C} /-33.3^{\circ} \mathrm{C}$ and maxima of $15.6{ }^{\circ} \mathrm{C} / 14.0^{\circ} \mathrm{C}$, respectively. However, the difference between the mean summer temperatures (June-August; Nettilling Lake: $4.6^{\circ} \mathrm{C}$; Iqaluit: $5.9{ }^{\circ} \mathrm{C}$; difference: $-1.3^{\circ} \mathrm{C}$ ) varies less than for the mean winter temperatures (September-May; $-18.8^{\circ} \mathrm{C},-15.8{ }^{\circ} \mathrm{C} ;-3^{\circ} \mathrm{C}$ ).

Furthermore, 30 lake and river water samples were analysed for stable water isotopes (Supplementary Table 2) and their $\delta^{18} \mathrm{O}$ value interpolated to cover the complete water body of Nettilling Lake (Fig. 4). The outflow Koukdjuak River was sampled every $10 \mathrm{~km}$ (7 samples) and showed a very uniform mean $\delta^{18} \mathrm{O}$ value of $-17.41 \pm 0.10 \%$ ( $\delta \mathrm{D}=-133.2 \pm 0.6 \%$ o, $\mathrm{n}=7)$. This river close to the camp was sampled during the expedition in 2013 which confirmed the results by revealing an almost identical isotopic 
Table 1

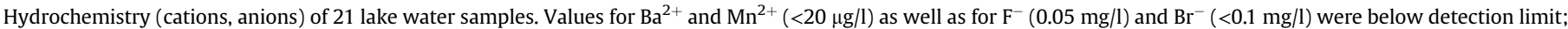
$\mathrm{PO}_{4}^{-}$was not analysed. Sample IDs can be seen on the lake map (Fig. 4).

\begin{tabular}{|c|c|c|c|c|c|c|c|c|c|c|c|c|c|}
\hline ID & Site & $\begin{array}{l}\mathrm{Al}^{3+}[\mu \mathrm{g} / \\
\mathrm{L}]\end{array}$ & $\begin{array}{l}\mathrm{Ca}^{2+}[\mathrm{mg} / \\
\mathrm{L}]\end{array}$ & $\begin{array}{l}\mathrm{Fe}^{2+/ 3+}[\mu \mathrm{g} / \\
\mathrm{L}]\end{array}$ & $\begin{array}{l}\mathrm{K}^{+}[\mathrm{mg} / \\
\mathrm{L}]\end{array}$ & $\begin{array}{l}\mathrm{Mg}^{2+}[\mathrm{mg} / \\
\mathrm{L}]\end{array}$ & $\begin{array}{l}\mathrm{Na}^{+}[\mathrm{mg} / \\
\mathrm{L}]\end{array}$ & $\begin{array}{l}\mathrm{Si}^{4+}[\mathrm{mg} / \\
\mathrm{L}]\end{array}$ & $\begin{array}{l}\mathrm{Sr}^{2+}[\mu \mathrm{g} / \\
\mathrm{L}]\end{array}$ & $\begin{array}{l}\mathrm{Cl}^{-}[\mathrm{mg} / \\
\mathrm{L}]\end{array}$ & $\begin{array}{l}\mathrm{SO}_{4}^{-}[\mathrm{mg} / \\
\mathrm{L}]\end{array}$ & $\begin{array}{l}\mathrm{NO}_{3}^{-}[\mathrm{mg} / \\
\mathrm{L}]\end{array}$ & $\begin{array}{l}\mathrm{HCO}_{3}^{-}[\mathrm{mg} / \\
\mathrm{L}]\end{array}$ \\
\hline 1 & North-East & 41 & 3.96 & 61 & $<0.2$ & 0.46 & 0.70 & 0.50 & $<20$ & 1.25 & 0.74 & 0.21 & 11.4 \\
\hline 2 & North-East & 31 & 4.91 & 92 & $<0.2$ & 0.51 & 0.73 & 0.43 & $<20$ & 1.39 & 0.86 & 0.20 & 15.1 \\
\hline 3 & North-East & 41 & 5.19 & 38 & $<0.2$ & 0.54 & 0.79 & 0.48 & $<20$ & 1.42 & 0.83 & 0.20 & 14.6 \\
\hline 4 & North-East & 29 & 4.60 & 48 & $<0.2$ & 0.50 & 0.79 & 0.46 & $<20$ & 1.27 & 0.81 & 0.19 & 10.4 \\
\hline 5 & Center & $<20$ & 9.52 & 34 & $<0.2$ & 0.78 & 0.86 & 0.26 & $<20$ & 1.91 & 1.37 & 0.16 & 29.7 \\
\hline 8 & Center & $<20$ & 9.70 & 273 & $<0.2$ & 0.84 & 0.94 & 0.25 & $<20$ & 1.97 & 1.52 & $<0,15$ & 26.1 \\
\hline 9 & Center & $<20$ & 8.47 & 478 & $<0.2$ & 0.77 & 0.81 & 0.28 & $<20$ & 1.85 & 1.35 & 0.15 & 21.7 \\
\hline 10 & North-East & 48 & 3.86 & 2383 & $<0.2$ & 0.46 & 0.76 & 0.47 & $<20$ & 1.36 & 0.70 & 0.19 & 11.7 \\
\hline 11 & Isurtuq River & 136 & 0.60 & 1564 & $<0.2$ & 0.25 & 0.46 & 0.87 & $<20$ & 0.57 & 0.57 & 0.23 & 1.68 \\
\hline 12 & Isurtuq River & 77 & 0.38 & 626 & $<0.2$ & 0.22 & 0.49 & 1.07 & $<20$ & 0.53 & 0.53 & 0.28 & 1.07 \\
\hline 14 & Isurtuq River & 131 & 0.37 & 1282 & $<0.2$ & 0.21 & 0.50 & 1.22 & $<20$ & 0.48 & 0.52 & 0.31 & 1.22 \\
\hline 16 & Koudjuak River & $<20$ & 12.7 & 265 & $<0.2$ & 0.89 & 0.87 & 0.23 & $<20$ & 2.08 & 1.91 & 0.16 & 38.9 \\
\hline 18 & Koudjuak River & $<20$ & 12.1 & 264 & $<0.2$ & 0.90 & 0.86 & 0.21 & $<20$ & 2.09 & 2.05 & $<0,15$ & 34.2 \\
\hline 20 & Koudjuak River & $<20$ & 12.0 & 284 & $<0.2$ & 0.91 & 0.91 & 0.23 & $<20$ & 2.04 & 1.86 & 0.16 & 30.0 \\
\hline 22 & Koudjuak River & $<20$ & 12.2 & 136 & $<0.2$ & 0.94 & 0.91 & 0.24 & $<20$ & 2.03 & 1.87 & $<0,15$ & 33.6 \\
\hline 24 & $\begin{array}{l}\text { Amadjuak } \\
\text { River }\end{array}$ & $<20$ & 14.0 & 893 & $<0.2$ & 1.07 & 0.78 & 0.32 & 21.0 & 1.96 & 3.26 & 0.17 & 34.3 \\
\hline 29 & Burwash Bay & 36 & 12.6 & 1146 & $<0.2$ & 0.90 & 0.75 & 0.41 & $<20$ & 1.90 & 2.54 & $<0,15$ & 28.8 \\
\hline 30 & Lagoon (NW) & $<20$ & 23.3 & 38 & 0.29 & 3.35 & 2.13 & 0.17 & 30.6 & 3.80 & 6.64 & 0.17 & 54.3 \\
\hline $\begin{array}{l}\mathrm{Ni}^{-} \\
2 \mathrm{~B}\end{array}$ & $\mathrm{Ni}-2 \mathrm{~B}$ & 142 & 1.12 & 161 & $<0.2$ & 0.27 & 0.50 & 0.77 & $<20$ & 0.80 & 0.46 & 0.24 & 0.92 \\
\hline BB & Burwash Bay & $<20$ & 12.0 & 618 & $<0.2$ & 0.83 & 0.68 & 0.28 & $<20$ & 1.73 & 1.98 & 0.19 & 30.0 \\
\hline MP & Center & $<20$ & 10.9 & 396 & $<0.2$ & 0.88 & 0.90 & 0.25 & $<20$ & 1.92 & 1.60 & 0.16 & 19.4 \\
\hline
\end{tabular}

composition $\left(\delta^{18} \mathrm{O}=-17.48 \%\right.$, $\delta \mathrm{D}=-134.4 \%$ ) . We believe that this value is representative for Nettilling Lake mean $\delta^{18} \mathrm{O}$ value indicating the relative contribution from the tributaries and from precipitation.

Four samples taken from the inflow of Isurtuq River and nearby locations had a mean oxygen isotope composition of $\delta^{18} \mathrm{O}=-18.80 \pm 0.21 \%$ o $(\delta \mathrm{D}=-141.2 \pm 2.5 \%$ o, $\mathrm{n}=4)$ whereas the inflow of Amadjuak River and the southern part of Burwash Bay showed significantly higher mean $\delta^{18} O$ values of $-16.39 \pm 0.10 \%$ $(\delta \mathrm{D}=-126.6 \pm 0.6 \%, \mathrm{n}=6)$. The rest of the samples ranged mostly between -17 and $-18 \%$. The lagoon sample (north of the outflow delta of Koukdjuak River, $\delta^{18} \mathrm{O}=-16.08 \%$, $\delta \mathrm{D}=-124.8 \%$ ) represents special hydrological conditions of a small isolated basin and was therefore not included in the interpolation.

The differences between the three locations (Mean value: Burwash Bay $\delta^{18} \mathrm{O}=-16.55 \pm 0.04 \%$ o, $\delta \mathrm{D}=-128.0 \pm 0.6 \%$; Magnetic Point $\delta^{18} \mathrm{O}=-17.19 \pm 0.03 \%$, $\delta \mathrm{D}=-132.1 \pm 0.3 \%$; Ni-2B $\delta^{18} \mathrm{O}=-18.74 \pm 0.06 \%$ o, $\delta \mathrm{D}=-141.7 \pm 1.0 \%$ ) confirm the local differences described above. Isotope-depth profiles down the water column showed a locally uniform isotope composition without significant gradients (Fig. 3).

\subsection{Oxygen isotopes in biogenic silica}

After purification, 38 out of 43 samples contained enough material for isotope analysis. Using Energy-Dispersive X-ray Spectroscopy (EDS) analysis for determining the degree of contamination 28 out of the remaining 38 cleaned samples had $\mathrm{Al}_{2} \mathrm{O}_{3}$ concentrations below $2.5 \%$ (mean value $1.5 \%$ ) and thus, showed only little contamination which was then corrected for (see section 2.4). Ten purified samples showed $\mathrm{Al}_{2} \mathrm{O}_{3}$ concentrations above $2.5 \%$ and were not used for isotope analysis. Chapligin et al. (2012a) proposed to use and correct for samples of up to $15 \%$ contamination. As the heavy fractions (from heavy liquid separations to separate diatoms in the light fraction from all other material) used as a 100\% contamination end-member showed comparably high $\mathrm{Al}_{2} \mathrm{O}_{3}$ concentrations (mean value 20.7\%) and a comparably high $\delta^{18} \mathrm{O}$ value of $+12.3 \%$, the 28 used samples were well within "allowed" correction limits with a mean calculated \% cont. of $7.2 \%$.

The oxygen isotope record from core Ni-2B (Fig. 6) shows a large general amplitude of more than 13\%. Minimum values of $\delta^{18} \mathrm{O}=+21.4 \%$ were observed at the very top of the core (average depth $4.25 \mathrm{~cm})$ close to the very top sample $(+21.5 \%, 1.75 \mathrm{~cm})$ and the sample below $(+22.3 \%$ o, $6.25 \mathrm{~cm})$. From $7.75 \mathrm{~cm}$ to $33.25 \mathrm{~cm}$, the oxygen isotope composition is rather stable $\left(\delta^{18} \mathrm{O}=+23.6 \pm 0.5 \%\right.$, $\mathrm{n}=10$ ). Then, the record shows a trend towards higher $\delta^{18} \mathrm{O}$ values from $38.25 \mathrm{~cm}$ to $62.75 \mathrm{~cm}$ where $\delta^{18} \mathrm{O}$ values increase from +23.4 to $+27.2 \%$. This is followed by a plateau of high $\delta^{18} \mathrm{O}$ values $\left(\delta^{18} \mathrm{O}=+33.7 \pm 0.7 \%\right.$, $\left.\mathrm{n}=5\right)$ reaching an absolute maximum in the record of $\delta^{18} \mathrm{O}=+34.6 \%$ at $78.75 \mathrm{~cm}$. The two bottom samples show a lower $\delta^{18} \mathrm{O}$ value again with $\delta^{18} \mathrm{O}=+26.8 \%$ and $+24.9 \%$ at 81.25 and $81.75 \mathrm{~cm}$, respectively.

\section{Discussion}

\subsection{Recent (isotope) hydrology}

All parameters $\left(\delta^{18} \mathrm{O}, \mathrm{pH}, \mathrm{DO}\right.$, electrical conductivity, temperature) analysed for the three different water profiles show that Nettilling Lake is a well-mixed lake with no developed thermocline and no other large gradients down the water column (Fig. 3). However, there are large regional differences between the three sites. The different water temperatures are due to the different water depth at the respective sampling sites. Shallower areas, in particular the island-rich eastern part in which coring site Ni-2B (mean temperature $7.4{ }^{\circ} \mathrm{C}$ ) is located or Burwash Bay $\left(9.4{ }^{\circ} \mathrm{C}\right.$ ) in the South heat up earlier than deeper sections of the central and western part of the lake such as the Magnetic Point site $\left(3.4^{\circ} \mathrm{C}\right)$. The differences in the oxygen isotope composition and the electrical conductivity are a result of the specific inflow regimes which can best be explained with the hydrochemical data (Table 1) and on the interpolation between the $\delta^{18} \mathrm{O}$ values of all lake water samples (Fig. 4).

The hydrochemistry of the analysed water samples shows differences between the subdivided north-eastern and southern lake 


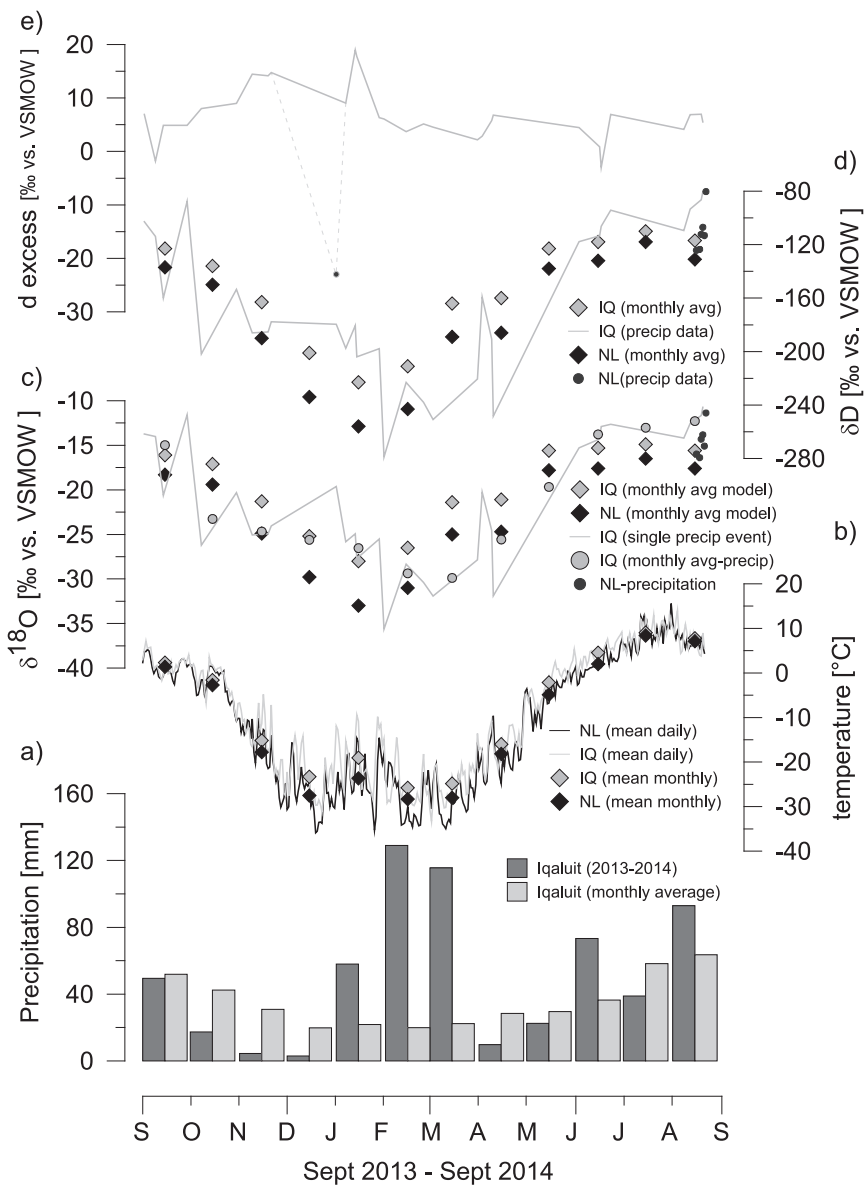

Fig. 5. (a) Monthly precipitation in Iqaluit (black: Sept 2013-Sept 2014; grey: monthly average precipitation, taken from http://www.iqaluit.climatemps.com/), (b) mean daily temperature from the climate station on-site at Nettilling Lake (black) and Iqaluit (grey) between Sept 2013 and 2014, (c, d, e) precipitation isotope data $\left(\delta^{18} \mathrm{O}, \delta \mathrm{D}\right.$, d excess) collected in Iqaluit between Sept 2013 and 2014. Precipitation and temperature data Iqaluit were taken from http://climate.weather.gc.ca/climateData/. Exact values can be found in the supplementary material (Supplementary Table 1). areas. The samples from Isurtuq River showed low ion concentrations $\left(\right.$ mean $\mathrm{c}\left(\mathrm{Ca}^{2+}\right)=0.5 \pm 0.1 \mathrm{mg} / \mathrm{L}$; mean $\mathrm{c}\left(\mathrm{HCO}_{3}^{-}\right)=1.3 \pm 0.3 \mathrm{mg} /$ $\mathrm{L} ; \mathrm{pH}$ 5.7) very likely due to major contributions of glacial runoff from Penny Ice Cap passing through Precambrian rocks (being the predominant bedrock on the North-East Side of the Lake) with only little to no additional dissolution at all. In the South the Ordovician carbonate-rich sedimentary rocks can be dissolved easier, resulting in higher ion concentrations and a bicarbonate-buffered system $\left(\right.$ mean $\mathrm{c}\left(\mathrm{Ca}^{2+}\right)=12.9 \pm 1.0 \mathrm{mg} / \mathrm{L} ;$ mean $\mathrm{c}\left(\mathrm{HCO}_{3}^{-}\right)=31.1 \pm 2.9 \mathrm{mg} / \mathrm{L}$; $\mathrm{pH} 6.1$ ). Interestingly the outflow of Koukdjuak River showed almost identical ion concentrations as those measured for the south of the Lake. This could be due to a time shift in major runoff events after snow/ice melt in spring and summer between Penny Ice Cap and Amadjuak Lake resulting in a snap-shot analysis of the hydrology where Amadjuak River brought a higher volume of water to the lake compared to Isurtuq River. However, the oxygen isotope composition which was measured from the same aliquot clearly shows a mean signal between the two inflows in the outflow (see below). The (north)-eastern part of the lake is extremely rich in small islands (Fig. 4). As a result, waves caused by winds which can be strong over this large open water body without any orographical barrier can reach large stretches of land (shorelines as well as islands) and effectively erode material. As a consequence, the Isurtuq River water which just drained into the north-eastern part of the lake could be enriched in ions. The samples taken in this area (Samples IDs 1, 2, 3, 4, 10) show that an increase in various ion concentrations occurs (mean $\mathrm{c}\left(\mathrm{Ca}^{2+}\right)=4.5 \pm 0.6 \mathrm{mg} / \mathrm{L}$; mean $\left.\mathrm{c}\left(\mathrm{HCO}_{3}^{-}\right)=12.7 \pm 2.1 \mathrm{mg} / \mathrm{L}\right)$ thereby supporting this assumption.

Regarding isotope hydrology, a relatively light isotope composition can be distinguished in the north-east with Isurtuq River acting as main inflow and one end-member here $\left(\delta^{18} \mathrm{O}=-18.80 \pm 0.21 \% ; \delta \mathrm{D}=-141.2 \pm 2.5 \% ; \mathrm{n}=4\right)$ whereas Amadjuak River draining Amadjuak and Mingo Lakes from the South shows a heavier isotope composition $\left(\delta^{18} \mathrm{O}=-16.39 \pm 0.10 \% ; \delta \mathrm{D}=-126.6 \pm 0.6 \% ; \mathrm{n}=6\right)$. Isurtuq River receives most of its water from Penny Ice Cap, a remnant of the retreat of Foxe Dome after the Last Glacial Maximum (Miller et al., 2005). Fisher et al. (1998) recovered two ice-cores (cores P95, P96) from Penny Ice Cap and showed that the $\delta^{18} \mathrm{O}$ values ( $1 \mathrm{~m}$ averages)

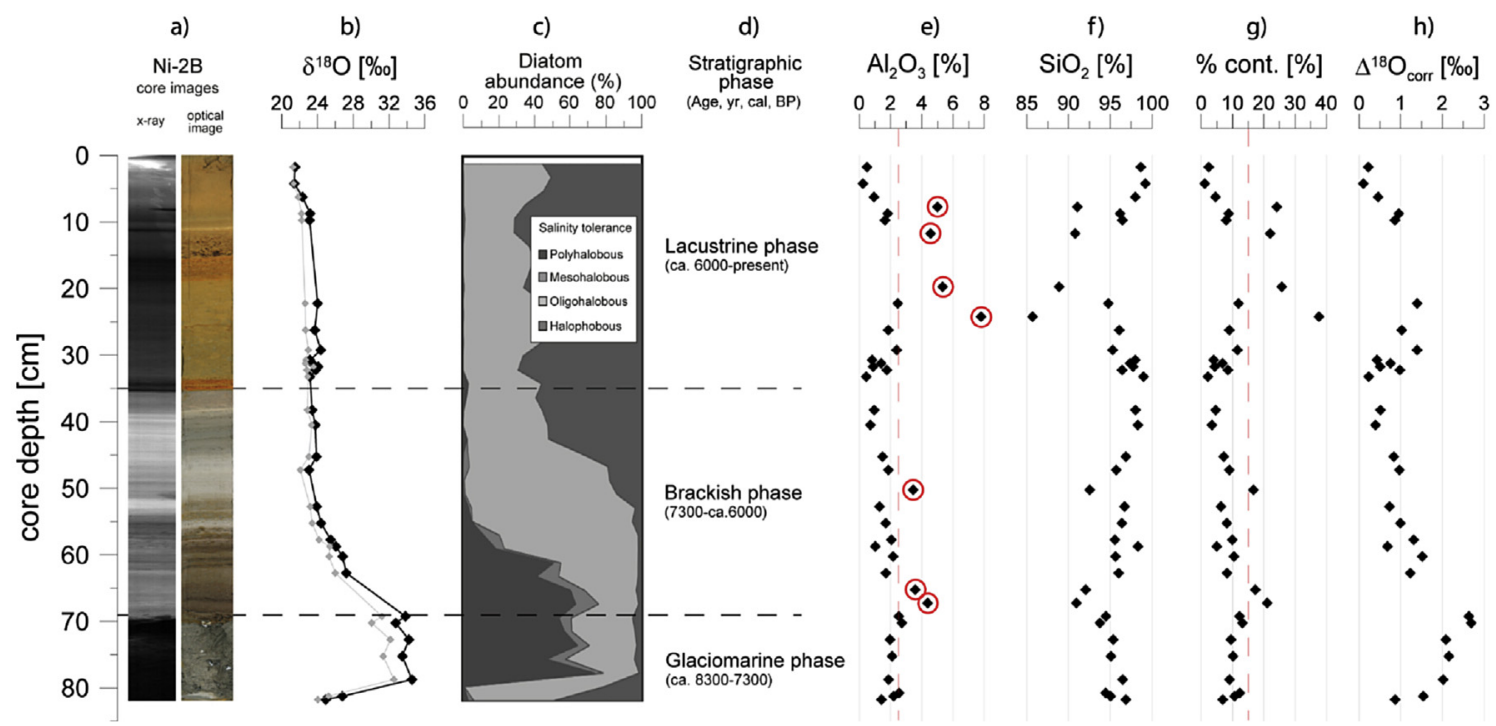

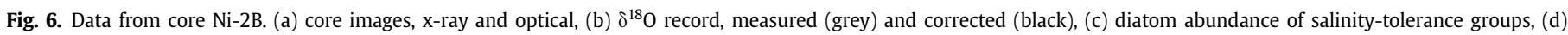

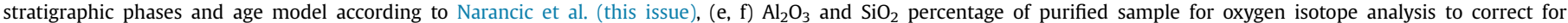

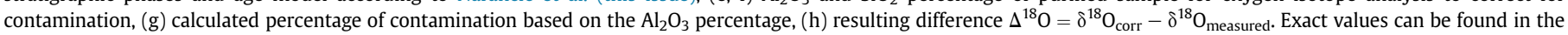
supplementary material (Supplementary Table 3). 
ranged between ca. -21 and $-25 \%$, with a mean value $300 \mathrm{~m}$ downcore of around $-24 \%$ (P95). As the straight-line distance between Nettilling Lake and Penny Ice Cap is about $130 \mathrm{~km}$ (and the Isurtuq River is meandering of high degree) this glacial run-off is "diluted" with precipitation and other runoff of heavier isotopic composition before draining into Nettilling Lake. In contrast, the second larger tributary (and end-member) Amadjuak River entering Nettilling Lake from the South shows a heavier isotope composition $\left(\delta^{18} \mathrm{O}=-16.39 \pm 0.10 \%\right.$; $\delta \mathrm{D}=-126.6 \pm 0.6 \%$; $\mathrm{n}=6$ ). The heavier isotope signal from the South can be explained by (1) the Amadjuak River draining Amadjuak and Mingo Lakes and therefore having a watershed extending to up to $150 \mathrm{~km}$ south of Nettilling Lake; (2) the Penny ice cap being located even further north than Nettilling Lake and at higher altitude. According to the $\mathrm{T}-\delta^{18} \mathrm{O}$ relationship (mean annual air temperature vs. $\delta^{18} \mathrm{O}$ of precipitation) by Dansgaard (1964), higher $\delta^{18} \mathrm{O}$ values correspond to lower latitudes and lower elevation in the catchment of these rivers. The (interpolated) oxygen isotope composition in the center of the lake ranges between -16.8 and $-17.7 \%$, with the outflow of Koukdjuak River showing a constant oxygen isotope signal of $-17.43 \pm 0.04 \%$ for the whole $80 \mathrm{~km}$ distance to Foxe Basin. Not taking direct precipitation input or wind-drifted snow input to the lake into account a two component end-member calculation using the mean $\delta^{18} \mathrm{O}$ values from both inflows $(-18.80 \%$; $-16.39 \%$ ) and a lake mean value of $-17.43 \%$, yields about $43 \%$ of the water volume originating from the North, whereas $57 \%$ of the lake water comes from the south.

When comparing the modelled annual isotope signal from precipitation between Iqaluit $(-18.6 \% 0)$ and Nettilling Lake $(-20.8 \%$ ) calculated by Bowen (2015, based on Bowen and Revenaugh, 2003), an offset between the two sites of $2.2 \%$ was observed. As no permanent precipitation sampling was possible at Nettilling Lake, the precipitation samples were taken at Iqaluit and analysed for their isotopic composition. Using this daily oxygen isotope data and daily temperature from Iqaluit, a $\mathrm{T}-\delta^{18} \mathrm{O}$ relation of $\delta^{18} \mathrm{O}=0.58 \mathrm{~T}-17.3 \%$ o $\left(\mathrm{r}^{2}=0.72\right)$ was determined which increases the quality of the correlation $\left(\mathrm{r}^{2}=0.91\right)$ when using monthly mean values: $\delta^{18} \mathrm{O}=0.47 \mathrm{~T}-17.5 \%$ (Fig. 7 ). The global T- $\delta{ }^{18} \mathrm{O}$ relationship was described by Dansgaard (1964) with $\delta^{18} \mathrm{O}=0.69 \mathrm{~T}-13.9 \%$ where $\mathrm{T}$ is the mean annual air temperature (MAAT). However, many regional $\mathrm{T}-\delta^{18} \mathrm{O}$ correlations exist, for example, for high latitudes/continental regions with lower gradients of about $0.5-0.6 \%$ / ${ }^{\circ} \mathrm{C}$ (Rozanski et al., 1993). The isotope-temperature relationship of $0.49 \% /{ }^{\circ} \mathrm{C}$ for interior Canada (Rosanzski et al., 1993; in Clark and Fritz, 1997) matches our Iqaluit gradient based on the monthly mean precipitation data $\left(0.47 \% \circ /{ }^{\circ} \mathrm{C}\right)$ well. The calculated annual mean temperature difference between Iqaluit and Nettilling Lake of $-2.4{ }^{\circ} \mathrm{C}$ would therefore result in a shift of mean $\delta^{18} \mathrm{O}$ precipitation from Iqaluit to Nettilling Lake in the order of $-1.1 \%$. Hence, the calculated isotopic shift between Iqaluit and Nettilling Lake should be between $-1.1 \%$ and $-2.2 \%$. The analysed offset between measured data during the two expeditions in August (mean monthly $\delta^{18} \mathrm{O}=-13.95 \%$ ) and the data from Iqaluit precipitation $\left(\delta^{18} \mathrm{O}=-12.28 \%\right.$ ) was $\Delta^{18} \mathrm{O}=-1.67 \%$ and seems to be reasonable in this context.

Subtracting the $\Delta^{18} \mathrm{O}$ of $-1.7 \%$ from the measured mean annual precipitation values $\left(-19.32 \%\right.$ ), this results in a mean annual $\delta^{18} \mathrm{O}$ precipitation signal at Nettilling Lake of $-21.02 \%$ which is in accordance with the calculated $\delta^{18} \mathrm{O}$ of $-20.8 \%$ for this site. Hence, the mean annual $\delta^{18} \mathrm{O}$ precipitation signal at Nettilling Lake should be around $-21 \%$.

Comparing this value to the observed oxygen isotope composition of the lake of about $\delta^{18} \mathrm{O}=-17.43 \%$ o the lake shows a significantly higher $\delta^{18} \mathrm{O}$ than anticipated if simply fed by precipitation. This could have several reasons. First, the actual

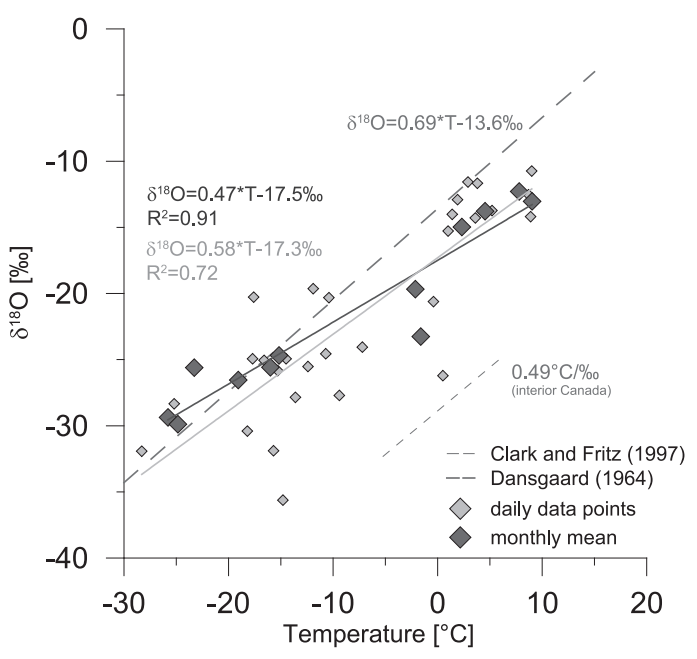

Fig. 7. Temperature- $\delta^{18} \mathrm{O}$ relation. Regression lines from single data (grey line) and mean monthly data (black line). Dansgaard MAAT $-\delta^{18} O$ relation dark grey line line, thick broken) and Jouzel mean monthly (?) temperature- $\delta{ }^{18} \mathrm{O}$ relation (dark grey line, thin broken).

$\delta^{18} \mathrm{O}_{\text {precipitation }}$ might be higher than the calculated mean value due to a shift in seasonality or an uptake of secondary moisture. The $\delta^{18} \mathrm{O}-\delta \mathrm{D}$ relation reveals that the precipitation both at Nettilling Lake and in Iqaluit marks on the GMWL for winter precipitation (snow; $\delta^{18} \mathrm{O}<-20 \%$ for all data points with daily temperatures $<0.5^{\circ} \mathrm{C}$ ) typical for the Arctic where as summer precipitation plots below the GMWL. Thus, the local meteoric water line for Iqaluit $\left(\mathrm{dD}=7.7 \delta^{18} \mathrm{O}+0.28 \%\right.$; $\left.\mathrm{R}^{2}=0.98\right)$ is indicative of the participation of secondary moisture, thereby suggesting a contribution of regional moisture from open water bodies to the precipitation signal resulting in a lower $d$ excess. This impact could be higher at Nettilling Lake being located $>80 \mathrm{~km}$ away from the nearest potential source (Foxe Basin) with hundreds of small lakes in between. Additionally, at Nettilling Lake there might be a slightly different seasonality of precipitation than in Iqaluit. A higher percentage of summer precipitation would lead to higher mean annual $\delta^{18} \mathrm{O}$ values than those calculated using Iqaluit data.

Second, evaporation could result in a depletion of ${ }^{16} \mathrm{O}$ in the lake water. However, at these high latitudes usually no significant lake evaporation exists as temperatures are low and lakes are covered by ice most of the year. This is supported by the $d$ excess data showing similar values for precipitation (d excess for Nettilling Lake precipitation from August 2013/August 2014 is between -6 and $10 \%$; mean annual d excess for precipitation at Iqaluit is 5.8\%o) and Nettilling Lake water (between 3 and 10\%o) which excludes major evaporation. Additionally the $\delta^{18} \mathrm{O}-\delta \mathrm{D}$ plot (Fig. 8) shows no large offset of lake water samples compared to the global meteoric water line (GMWL). However, the heavier (less negative) the isotope composition the larger is the offset from the GMWL illustrating a slightly higher evaporation in the southern part of the lake $\left(\delta^{18} \mathrm{O}>-18 \%\right.$ ) which could lead to water depleted in ${ }^{16} \mathrm{O}$. This southern part is free of ice before other parts, thus with longer icefree seasons and a longer exposure to potential evaporation. According to Fig. 8 , this could, however, compensate for only $0.5 \%$ at the most.

Finally, the residence time can severely influence the reaction of the isotopic signal of lake water to $\delta^{18} \mathrm{O}$ shifts in precipitation or hydrological changes. A lower $\delta^{18} \mathrm{O}$ value than that of the recent precipitation could thus result from past conditions. Assuming stable hydrological conditions, this would mean that in the past 
lower $\delta^{18} \mathrm{O}$ values in precipitation and therefore a cooler mean annual air temperature must have existed. However, ice-core data from Penny Ice Cap show a shift in $\delta^{18} \mathrm{O}$ values of ca. $1 \%$ towards higher values when going back in time from the present-day to ca. 8ka BP during the Holocene Thermal Maximum (Fisher et al., 1998; core P95). Additionally, the lake is exposed to two massive inflows from the North-East and the South flushing the lake water annually through the more than $1 \mathrm{~km}$ wide Koukdjuak River to Foxe Basin ( $5 \mathrm{~km}$ width at the site where the outflow leaves Nettilling Lake). Thus, despite the large lake size a short residence time is assumed for Nettilling Lake. In summary, the isotopic composition of the lake water shows a well-mixed and regionally different signal dependent on local precipitation, inflows and a potentially highly variable hydrological environment.

\section{2. $\delta^{18} \mathrm{O}_{\text {diatom }}$ vs. $\delta^{18} \mathrm{O}_{\text {water }}$}

After correcting the $\delta^{18} \mathrm{O}_{\text {measured }}$ by mass-balance calculation (using $\mathrm{Al}_{2} \mathrm{O}_{3}$ sample $/ \mathrm{Al}_{2} \mathrm{O}_{3}$ cont analysed by EDS for determining the percentage of contamination), the $\delta^{18} \mathrm{O}_{\text {corr }}$ value.

of the most recent diatom sample is $21.5 \%$ o $(1.5-2 \mathrm{~cm}$ depth). When comparing this value with the recent oxygen isotope signal from water of $\delta^{18} \mathrm{O}_{\text {water }}=-18.7 \pm 0.06 \%$ (average and standard deviation calculated from all values in $10 \mathrm{~m}$ water profile at $\mathrm{Ni}-2 \mathrm{~B}$ site), a $\Delta^{18} \mathrm{O}_{\text {silica-water }}$ of $1000 \ln \alpha_{(\text {silica-water })}=40.2 \%(\alpha=1.0410)$ was determined.

The fractionation factor $\alpha$ between silica and water depends on the considered system (cultivated/fresh silica-water; fossil silicawater; quartz-water) as well as on temperature (Labeyrie, 1974). The diatom-temperature coefficient in lacustrine systems is approximately $-0.2 \% /{ }^{\circ} \mathrm{C}$ as analysed by various studies (Brandriss et al., 1998; Dong and JingTai, 2010; Moschen et al., 2005; Dodd et al., 2012). For the recent average temperature for the photic zone at Nettilling Lake of $7.4{ }^{\circ} \mathrm{C}$ (as measured at site Ni-2B), the general $1000 \ln \alpha_{\text {(silica-water) }}$ varies between 34.6\% (following 1000 In $\alpha_{\text {(silica-water })}=15.56\left(10^{3} / \mathrm{T}\right)-20.92$; Brandriss et al., 1998) and $40.6 \%$ o $\left(\mathrm{t}\left[{ }^{\circ} \mathrm{C}\right]=5-4.1^{*}\left(\delta \mathrm{SiO}_{2}-\delta \mathrm{H}_{2} \mathrm{O}-40\right.\right.$; Labeyrie, 1974$)$ for freshwater and cultivation studies on recent diatoms, $41.9 \%$ for fossil sediments $\left(1000\right.$ In $\alpha_{\text {(silica-water) }}=3.26 \times 10^{6} / \mathrm{T}^{2}+0.45$; Juillet-Leclerc and Labeyrie, 1987) and $43.5 \%$ for the quartz-water fractionation $\left(1000\right.$ In $\alpha_{\text {(quarz-water })}=-2.9+3.65 \times 106 / \mathrm{T}^{2}$; Sharp and Kirschner, 1994). Hence, the silica water fractionation determined from this study on the recent system at Nettilling Lake corresponds closely to the proposed fractionation for fossil sediments at $7.4{ }^{\circ} \mathrm{C}$. As this reflects well the known silica-water fractionation in fossil sediments, it provides evidence for the existence of an isotopic equilibration of biogenic silica with the surrounding water and demonstrates the usefulness of the site for applying this proxy for paleo-reconstructions.

\subsection{Postglacial glaciomarine to lacustrine transition}

A general amplitude in the oxygen isotope record of more than $13 \%$ already reveals extreme environmental changes. Several controls on the $\delta^{18} \mathrm{O}_{\text {diatom }}$ signal in sediment records are known. The lake temperature in which the diatoms grow can have an impact (of ca. $-0.2 \% /{ }^{\circ} \mathrm{C}$ ) on the isotope signal (Brandriss et al., 1998; Moschen et al., 2005; Dodd et al., 2012). As Nettilling Lake is a large arctic lake with a comparably big water volume we can assume that lake temperature changes are rather small due to the following reasons: Diatoms are phototrophic organisms and the major blooming period in arctic lakes mainly occurs during openwater conditions which are between the end of July and late September. Oliver (1964) measured the water temperature in the respective summer months at 5 locations with all sites yielding a variation of less than $3{ }^{\circ} \mathrm{C}$ with no gradient down the water column (in the range of $\Delta \mathrm{T}=3{ }^{\circ} \mathrm{C}=-0.6 \%$ ). As the lake is well-mixed with no thermocline and a measured Secchi disc depth of mostly greater than $10 \mathrm{~m}$ (Oliver, 1964) this illustrates a large water volume of similar temperature where diatoms grow. Comparing a potential $\delta^{18} \mathrm{O}_{\text {diatom }}$ change of about $-0.6 \%$ to the overall $\delta^{18} \mathrm{O}$ amplitude in the record of more than $13 \%$ we conclude that the impact of lake temperature on the $\delta^{18} \mathrm{O}_{\text {diatom }}$ signal is negligible and can be excluded.

Consequently, as in many other lakes (Chapligin et al., 2012b; Kostrova et al., 2013; Meyer et al., 2015) the major impact factor must be the isotopic change of the lake water. This change can originate from either an isotopic variation in precipitation (mainly forced by different air temperatures) or by a changing hydrological environment. The mean annual air temperature (MAAT) at surface is directly related to the mean annual $\delta^{18} \mathrm{O}$ precipitation signal (shift of $+0.47 \% \circ /{ }^{\circ} \mathrm{C}$ as calculated above). Pollen records from several Baffin Island lakes indicate that middle Holocene temperatures were 1 or $2{ }^{\circ} \mathrm{C}$ warmer than present (Wolfe, 2003; Kerwin et al., 2004). Briner et al. (2006) found that during the Holocene Thermal Maximum between 10,000 and 8500 cal yr BP, the chironomid-inferred summer temperature was $5{ }^{\circ} \mathrm{C}$ warmer than today. According to Narancic et al. (this issue), core Ni-2B contains sediment extending back only to ca. 8300 cal yr BP. Even if assuming a change of $5{ }^{\circ} \mathrm{C}$ air temperature this would result in a $\delta^{18} \mathrm{O}_{\text {diatom }}$ change of only $2.5 \%$. Hence, there has to be a hydrological reason for this massive shift in the lake water isotope a)

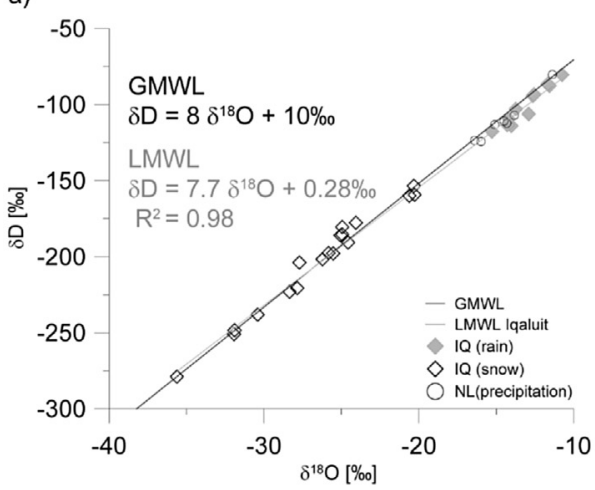

b)

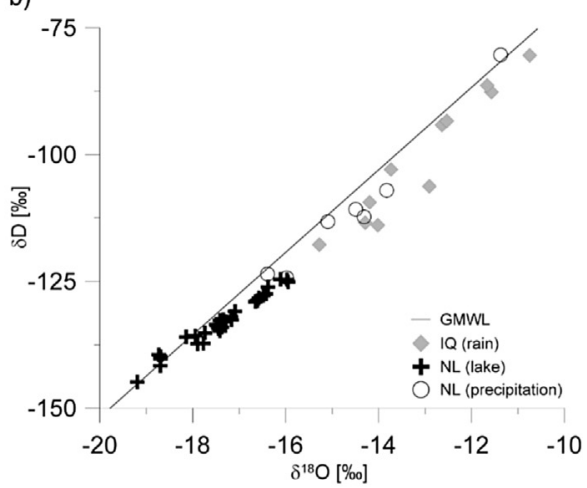

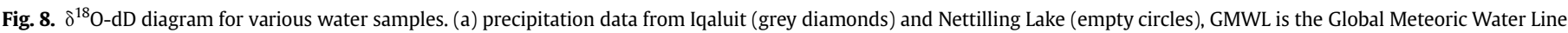

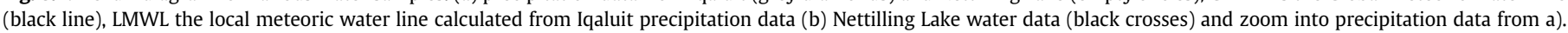


composition of the complete record.

It is known that Nettilling Lake and the surrounding region has been covered by the Laurentide Ice Sheet (LIS) during the Last Glacial Maximum. With post-glacial warming, the Foxe Dome progressively separated from the LIS which resulted in an inflow of marine waters into the Foxe Basin about 8000 to $7500{ }^{14} \mathrm{C} \mathrm{BP}$ (Prest and Rampton, 1968; Barber et al., 1999; Miller et al., 2005). Marine waters penetrated into Nettilling Basin at ca. 6600 cal. BP after the final breakdown of the Foxe Dome (Blake, 1966; De Angelis and Kleman, 2007; Narancic et al., this issue). About ca. 5000 cal. BP, the current lacustrine freshwater conditions came into existence by progressive glacio-isostatic uplift (Blake, 1966; Fulton, 1975). Thus, the lake experienced a shift from isotopically enriched marine water to more depleted lacustrine water. This is well reflected in the $\delta^{18} \mathrm{O}$ downcore record which can be split into three zones showing a glaciomarine (69-79 $\mathrm{cm}$ core depth, mean $\left.\delta^{18} \mathrm{O}=+33.7 \pm 0.7 \%, \mathrm{n}=5\right)$, a lacustrine $(0-35 \mathrm{~cm},+23.2 \pm 0.9 \%$, $\mathrm{n}=13$ ) as well as an intemediate brackish transition phase in between $(35-69 \mathrm{~cm} ;+23.4$ to $+27.2 \%$; $\mathrm{n}=10$ ). This is strongly supported by the diatom assemblage changes of salinity-tolerance groups (Fig. 6; detailed counts for diatom assemblages are presented in Narancic et al., this issue) in which the diatom taxa are arranged in order of salinity tolerances (polyhalobous = marine species with tolerance limit within the range 20\%o-35\%; mesohalobous $=$ brackish water species with an optimum range between $0.2 \%$ and $30 \%$, oligohalobous = indifferent taxa living in both brackish and freshwaters; halophobous = exclusively freshwater taxa (Narancic et al., this issue)).

Regarding the glaciomarine zone, it is questionable if full marine conditions existed during the peak of the marine influence at site $\mathrm{Ni}-2 \mathrm{~B}$. Tan and Strain (1996) observed a mean $\delta^{18} \mathrm{O}$ value of $-2.3 \%$ analysing marine water from four sites in Foxe Basin with the isotope composition being in equilibrium with sea ice from the area. Using the calculated recent silica-water fractionation, this should result in a $\delta^{18} \mathrm{O}_{\text {diatom }}$ value of $+37.9 \%$ for full-marine con-

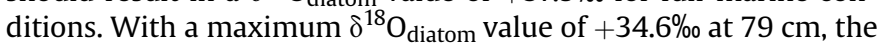
conditions come close to only $80 \%$ marine conditions and were surely still influenced by an isotopically depleted water source. This could have been either precipitation or, as the site Ni-2B is close to the inflow of Isurtuq River, run-off from the remaining Penny Ice Cap to the Nettilling Basin after Foxe Dome ice-front retreat eastwards releasing enough meltwater could support this hypothesis. Further evidence in support of this assumption is provided by the last two data points of the record. The two lowermost samples show a significantly lighter isotopic composition $\left(\delta^{18} \mathrm{O}=+26.8 \%\right.$ and $+24.9 \%$ ) when compared to the glaciomarine phase which could originate from a freshwater pulse released by glacial retreat run-off before the onset of marine influence. At the same depth, the diatom assemblage shows a similar trend towards lower salinity supporting this assumption.

Comparing the onset of the brackish phase in the diatom assemblage to the one on the $\delta^{18} \mathrm{O}_{\text {diatom }}$ record, a slight delay in the reaction of the diatom assemblage can be observed at core depths of $60-69 \mathrm{~cm}$ and $53-43 \mathrm{~cm}$. This can be explained by a longer existence of salt-tolerant species despite a changing isotope composition in the lake and hence, by a slower adaptation of the diatom assemblage to the changing environment. The oxygen isotopes in biogenic silica followed the isotopic shift of the lake water faster and without this delay. Another reason could be that denser water of higher salinity could have been trapped in some deeper parts of the lake providing a relictic habitat for salt-tolerant species.

As stated in section 4.2 , the sub-recent $\delta^{18} \mathrm{O}_{\text {diatom value matches }}$ the published lake water-silica fractionation while $\delta^{18} \mathrm{O}$ values of the recent lake water and mean $\delta^{18} \mathrm{O}$ values of precipitation are comparable. These two findings, the hydrochemistry and the recent diatom assemblage allow to conclude that $100 \%$ freshwater conditions exist today. Focusing on this lacustrine part of the record from $35 \mathrm{~cm}$ core depth upwards, relatively constant hydrological conditions were established which adjusted after the shift towards a lacustrine environment (glaciomarine vs. lacustrine; see salinity tolerance groups of diatom assemblage in Fig. 6). Assuming also a short residence time (as discussed in section 4.1) the $\delta^{18} \mathrm{O}_{\text {diatom }}$ would mainly reflect $\delta^{18} \mathrm{O}_{\text {precipitation. }}$ A slight decrease in $\delta^{18} \mathrm{O}_{\text {diatom }}$ from $23.7 \%$ to $21.5 \%$ of about $1.8 \%$ up the core can be observed, mainly visible in the upper $10 \mathrm{~cm}$ of the core. Thus, using the regional $\delta^{18} \mathrm{O}-\mathrm{T}$ relation of $0.47 \%{ }^{\circ}{ }^{\circ} \mathrm{C}$ this would be equivalent to a decrease of $3.7^{\circ} \mathrm{C}$ in mean annual air temperature. However, there are three uncertainties: (1) a seasonality change in the winter/ summer precipitation ratio for a longer time period is not likely for a large lake such as Nettilling Lake but could also slightly change the isotope composition of the lake water; (2) Uncertainties of the exact regional $\delta^{18} \mathrm{O}-\mathrm{T}$ relation exist (see discussion in section 4.1.); (3) The standard deviation in the oxygen isotope measurements of diatom silica is around $\pm 0.2 \%$. Taking these three uncertainties into account this permits to suggest a regional late Holocene cooling trend in the order of $4{ }^{\circ} \mathrm{C}$.

The age model from Narancic et al. (this issue) sets the ages for the phase changes at $69 \mathrm{~cm}$ to $7300 \mathrm{yr}$ cal BP (glaciomarine to brackish) and at $35 \mathrm{~cm}$ to $6000 \mathrm{yr}$ cal BP (brackish to lacustrine). This was interpreted in a sense that Foxe Basin deglaciation happened approximately 400 years earlier than previously assumed (Narancic et al., this issue). Based on our diatom isotope data we infer that the mean annual air temperature decreased by about $3.7^{\circ} \mathrm{C}$ within the last $6000 \mathrm{yr}$ cal BP. This supports previous studies with a published temperature amplitude of late-Holocene cooling for the greater region around Baffin Island of around $3{ }^{\circ} \mathrm{C}$ (e.g., Andrews et al., 1981; Short et al., 1985; Dahl-Jensen et al., 1998), as well as results obtained from other diatom isotope studies in the Arctic (Shemesh et al., 2001; Chapligin et al., 2012a).

\section{Conclusions}

This study presents the recent isotope hydrology and hydrochemistry of Nettilling Lake, Baffin Island, the largest freshwater basin in the Canadian Arctic Archipelago. Additionally, a $\delta^{18} \mathrm{O}_{\text {diatom }}$ record from the $82 \mathrm{~cm}$ long sediment core $\mathrm{Ni}-2 \mathrm{~B}$ was determined and interpreted.

The well-mixed lake shows regionally different isotopic influences with a heavier isotope composition $\left(\delta^{18} \mathrm{O}=-18.80 \pm 0.21 \%\right.$ ) from Amadjuak River in the South and water of lighter isotopic composition $\left(\delta^{18} \mathrm{O}=-16.39 \pm 0.10 \%\right.$ o $)$ which is transported to the lake from the north-east by Isurtuq River and hence mostly originating from Penny Ice Cap. Evidence for this two-component mixing system is further provided by the lake's hydrochemistry. The Isurtuq River shows very low ion concentrations as the glacial runoff from Penny Ice Cap flows through Precambrian rocks with negligible dissolution processes. Amadjuak River in the South cuts through Ordovician limestones more prone to dissolution, resulting in higher ion concentrations and a bicarbonate-buffered system. The mean isotope composition of the lake was calculated for the lake center and the outflow $\left(\delta^{18} \mathrm{O}=-17.43 \pm 0.04 \%\right.$ ) suggesting that a similar water volume originates from both inflows.

Precipitation was sampled for isotope analysis in Iqaluit (app. $300 \mathrm{~km}$ south of Nettilling Lake) being the closest possible location for year-round observations. Excluding a meteorological station in the very North of Baffin Island, the area is void of any stations being part of the Canadian or Global Network for Isotopes in Precipitation (CNIP, GNIP). It is planned to integrate this station into the respective networks. A local meteoric water line $(\mathrm{dD}=7.7$ 
$\delta^{18} \mathrm{O}+0.28 \%$ ) indicative of secondary moisture was determined and a local $\delta^{18} \mathrm{O}$-T relation of $\delta^{18} \mathrm{O}=0.47 \mathrm{~T}-17.5 \%$ ( $\left.\mathrm{r} 2=0.91\right)$ was established for Iqaluit matching the published gradient of $0.49 \% /{ }^{\circ} \mathrm{C}$ for interior Canada (Rozanski et al., 1993).

The calculated mean annual $\delta^{18} \mathrm{O}_{\text {precipitation value (ca. }-21 \% \text { ) }}$ corresponds to the recent mean $\delta^{18} \mathrm{O}_{\text {water }}$ signal. The offset can be explained by $\delta^{18} \mathrm{O}_{\text {precipitation values being higher than expected due }}$ to the contribution of regional moisture from local and regional open water bodies to the precipitation signal, or a shift in seasonality at Nettilling Lake towards increased summer precipitation. According to the $\delta^{18} \mathrm{O}-\delta \mathrm{D}$ plot, evaporation plays only a minor role in the southern part of the lake due to earlier ice-break up.

Analysing $\delta^{18} \mathrm{O}_{\text {diatom }}$ for the most recent core sample, a $\Delta^{18} \mathrm{O}_{\text {silica- }}$ water of $1000 \ln \alpha_{\text {(silica-water })}=40.2 \%$ o $(\alpha=1.0410)$ was determined reflecting well the known silica-water fractionation in sediments. This demonstrates the applicability of this proxy for paleoreconstructions for the lake.

The downcore variations in the $\delta^{18} \mathrm{O}_{\text {diatom }}$ signal of more than $13 \%$ are mainly induced by the change of the isotopic composition of the lake water which changed dramatically due to a shift from glaciomarine towards lacustrine conditions accompanied by a shift in the degree of salinity. Three zones could be identified, namely a glaciomarine $\quad(69-79 \mathrm{~cm}$ core depth, mean $\delta^{18} \mathrm{O}_{\text {diatom }}=+33.7 \pm 0.7 \%$ ) , a lacustrine $(0-35 \mathrm{~cm},+23.2 \pm 0.9 \%$ ) , as well as a brackish water transitional zone in between (35-69 cm; +23.4 to $+27.2 \%$ ).

Applying the age model by Narancic et al. (this issue) to the transition zones at $69 \mathrm{~cm}$ (glaciomarine to brackish, $7300 \mathrm{yr}$ cal. BP) and $35 \mathrm{~cm}$ (brackish to lacustrine; $6000 \mathrm{yr}$ cal. BP) our results suggest that Foxe Basin deglaciation happened approximately 400 years earlier than previously thought. Additionally, when assuming constant hydrological conditions and that $\delta^{18} \mathrm{O}_{\text {diatom }}$ directly corresponds to $\delta^{18} \mathrm{O}_{\text {lakewater }}$ to $\delta^{18} \mathrm{O}_{\text {precipitation within the last }}$ $6000 \mathrm{yr}$ cal BP, the mean annual air temperature being the relevant

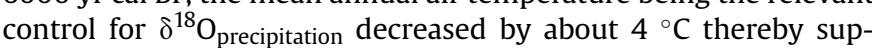
porting previous studies with a published temperature amplitude of late-Holocene cooling for the Baffin Island region of around $3^{\circ} \mathrm{C}$.

Comparing the mean $\delta^{18} \mathrm{O}_{\text {diatom }}$ value of the glaciomarine zone to the value modelled $(+37.9 \%$ ) by the determined water-silica fractionation and the marine oxygen isotope composition in Foxe Basin, it can be concluded that we never had full marine conditions at this site. A glacial meltwater run-off $\left({ }^{18} \mathrm{O}\right.$ depleted) from the remaining Penny Ice Cap to the Nettilling basin is proposed after the ice-front of the former Foxe Dome retreated eastwards. This is further supported by the two lowermost samples $(81-82 \mathrm{~cm})$ showing a significantly lighter isotopic composition than in the glacio-marine phase $\left(\delta^{18} \mathrm{O}=+26.8 \%\right.$ and $+24.9 \%$ ) , but comparable to the brackish water phase. Hence, by reconstructing $\delta^{18} \mathrm{O}_{\mathrm{la}}$ kewater in a hydrological setting that was in transition from glaciomarine to brackish and lacustrine conditions, we demonstrated for the first time that the parameter $\delta^{18} \mathrm{O}_{\text {diatom }}$ can be indirectly used as a proxy for paleosalinity changes. Additionally, this parameter may be successfully used as an air temperature proxy in sections of the same core where hydrological conditions can be assumed to be constant.

\section{Acknowledgements}

This work was co-funded by the Natural Sciences and Engineering Research Council (NSERC) of Canada (Project No. 1700432008), the Canadian Polar Continental Shelf Program (PCSP; Project No. 61313 and 64314), the Northern Scientific Training Program (NSTP, Canada) and the German Ministry for Education and Research (BMBF; Project No. 01DM14009). Denis Sarrazin (Centre d'Études Nordiques; CEN), Steve Lodge (United Helicopters of
Newfoundland) as well as Jim Leafloor and Pat Rakowski (Canadian Wildlife Service) are greatfully thanked for their field work support and for facilitating access to the Canadian Wildlife Service camp at Nikku Island, Nunavut. Additionally we are thankful for the logistical support from Centre for Northern Studies (CEN). Rick Armstrong from the Nunavut Research Institute (NRI) is greatly acknowledged for on-site support at Iqaluit and sampling precipitation. Oliver Weingart from ETH Zürich is greatly thanked for an internal ring test while the expedition crew was stuck in the field. A sincere gratitude goes to Juliane Leister, Lutz Schoenicke and Antje Eulenburg (all from AWI) for their work in the laboratory.

\section{Appendix A. Supplementary data}

Supplementary data related to this article can be found at http:// dx.doi.org/10.1016/j.quascirev.2016.03.028.

\section{References}

Andrews, J.T., Davis, P.T., Mode, W.N., Nichols, H., Short, S.K., 1981. Relative departures in July temperatures in northern Canada for the past $6000 \mathrm{yr}$. Nat. Nat. 289, 164-167.

Axford, Y., Briner, J.P., Miller, G.H., Francis, D.R., 2009. Paleoecological evidence for abrupt cold reversals during peak Holocene warmth on Baffin Island, Arctic Canada. Quat. Res. 71, 142-149. http://dx.doi.org/10.1016/j.yqres.2008.09.006.

Barber, D.C., Dyke, a., Hillaire-Marcel, C., Jennings, a. E., Andrews, J.T., Kerwin, M.W., Bilodeau, B., McNeely, R., Southon, J., Morehead, M.D., Gagnon, J.-M., 1999. Forcing of the cold event of 8,200 years ago by catastrophic drainage of Laurentide lakes. Nature 400, 344-348. http://dx.doi.org/10.1038/22504.

Blake, J.W., 1966. End moraines an deglaciation chronology in northern Canada with special reference southern Baffin Island. Geol. Surv. Can.

Bowen, G.J., 2015. The Online Isotopes in Precipitation Calculator, Version 2.2. http://www.waterisotopes.org.

Bowen, G.J., Revenaugh, J., 2003. Interpolating the isotopic composition of modern meteoric precipitation. Water Resour. Res. 39 (10), 1299,. http://dx.doi.org/ 10.129/2003WR002086 (for annual average values).

Brandriss, M.E., O'Neil, J.R., Edlund, M.B., Stoermer, E.F., 1998. Oxygen isotope fractionation between diatomaceous silica and water. Geochim. Cosmochim. Acta $62,1119-1125$.

Brewer, T.S., Leng, M.J., Mackay, A.W., Lamb, A.L., Tyler, J.J., Marsh, N.G., 2008. Unravelling contamination signals in biogenic silica oxygen isotope composition; the role of major and trace element geochemistry. JQS. J. Quat. Sci. 23, $321-330$.

Briner, J.P., Michelutti, N., Francis, D.R., Miller, G.H., Axford, Y., Wooller, M.J., Wolfe, A.P., 2006. A multi-proxy lacustrine record of Holocene climate change on northeastern Baffin Island, Arctic Canada. Quat. Res. 65, 431-442.

Chapligin, B., Meyer, H., Friedrichsen, H., Marent, A., Sohns, E., Hubberten, H.W., 2010. A high-performance, safer and semi-automated approach for the $\delta^{18} \mathrm{O}$ analysis of diatom silica and new methods for removing exchangeable oxygen. Rapid Comm. Mass Spectrom. 24, 2655-2664.

Chapligin, B., Leng, M.J., Webb, E.A., Alexandre, A., Dodd, J.P., Ijiri, A., Lücke, A., Shemesh, A., Abelmann, A., Herzschuh, U., Longstaffe, F.J., Meyer, H. Moschen, R., Okazaki, Y., Rees, N.H., Sharp, Z.D., Sloane, H.J., Sonzogni, C., Swann, G.E.A., Sylvestre, F., Tyler, J.J., Yam, R., 2011. Inter-laboratory comparison of oxygen isotopes from biogenic silica. Geochim. Cosmochim. Acta 75, 7242-7256. http://dx.doi.org/10.1016/j.gca.2011.08.011.

Chapligin, B., Meyer, H., Bryan, A., Snyder, J., Kemnitz, H., 2012a. Assessment of purification and contamination correction methods for analysing the oxygen isotope composition from biogenic silica. Chem. Geol. 300-301, 185-199.

Chapligin, B., Meyer, H., Swann, G.E.A., Meyer-Jacob, C., Hubberten, H.W., 2012b. A 250 ka oxygen isotope record from diatoms at Lake El'gygytgyn, far east Russian Arctic. Clim. Past. 8, 1621-1636.

Clark, I., Fritz, P., 1997. Environmental Isotopes in Hydrogeology. CRC Press/Lewis Publishers, Boca Raton, New York.

Clayton, R.N., Mayeda, T.K., 1963. The use of bromine pentafluoride in the extraction of oxygen from oxides and silicates for isotopic analysis. Geochim. Cosmochim. Acta 27, 43-52.

Dahl-Jensen, D., Mosegaard, K., Gundestrup, N., Johnsen, S.J., Hansen, A.W., Clow, G.D., Balling, N., 1998. Past temperatures directly from the Greenland ice sheet. Science 282, 268-271.

De Angelis, H., Kleman, J., 2007. Palaeo-ice streams in the Foxe/Baffin sector of the Laurentide ice sheet. Quat. Sci. Rev. 26, 1313-1331. http://dx.doi.org/10.1016/ j.quascirev.2007.02.010.

Dodd, J.P., Sharp, Z.D., Fawcett, P.J., Brearley, A., McCubbin, F.M., 2012. Rapid postmortem maturation of diatom silica oxygen isotope values. Geochem. Geophys. Geosystems 13 (9), 009014.

Dong, L., JingTai, H., 2010. Temperature-induced fractionation of oxygen isotopes of diatom frustules and growth water in Lake Sihailongwan in Northeast China. Chin. Sci. Bull. 55, 3794-3801. 
Fisher, D.A., Koerner, R.M., Bourgeois, J.C., Zielinski, G., Wake, C., Hammer, C.U., Clausen, H.B., Gundestrup, N.S., Johnsen, S., Goto-Azuma, K., Hondoh, T. Blake, E., Gerasimoff, M., 1998. Penny ice cap cores, Baffin island, Canada, and the Wisconsinan Foxe Dome connection: two states of Hudson bay ice cover. Science 279, 692-695.

Fulton, R.J., 1975. Quaternary geology of Canada and Greenland. Geol. Surv. Can. Geol. Can. No. 1.

Gonfiantini, R., 1978. Standards for stable isotope measurements in natural compounds. Nature 271, 534-536.

Jacobs, J.D., Headley, A.N., Maus, L.A., Mode, W.N., et Simms, E.L., 1997. Climate and vegetation of the interior lowlands of southern Baffin Island : long-term stability at the low arctic limit. Arctic 50 (2), 167-177.

Jacobs, J.D., Grondin, L.D., 1988. The influence of an arctic large-lakes system on mesoclimate in South-Central Baffin Island, N.W.T., Canada. Dep. Geogr. Gt. Lakes. Inst. Univ. Windsor. Arct. Antarct. Alp. Res. 20, 212-219.

Joynt III, E.H., Wolfe, A.P., 2001. Paleoenvironmental inference models from sediment diatom assemblages in Baffin Island lakes (Nunavut, Canada) and reconstruction of summer water temperature. Can. J. Fish. Aquat. Sci. 58, $1222-1243$.

Juillet-Leclerc, A., Labeyrie, L., 1987. Temperature dependence of the oxygen isotopic fractionation between diatom silica and water. Earth Planet. Sci. Lett. 84, 69-74.

Kerwin, M.W., Overpeck, J.T., Webb, R.S., Anderson, K.H., 2004. Pollen-based summer temperature reconstructions for the eastern Canadian boreal forest, subarctic, and Arctic. Quat. Sci. Rev. 23, 1901-1924.

Kostrova, S.S., Meyer, H., Chapligin, B., Kossler, A., Bezrukova, E.V., Tarasov, P.E., 2013. Holocene oxygen isotope record of diatoms from Lake Kotokel (southern Siberia, Russia) and its palaeoclimatic implications. Quat. Int. 290-291, 21-34.

Labeyrie, L.J., 1974. New Approach to surface seawater paleotemperatures using ${ }^{18} \mathrm{O} /{ }^{16} \mathrm{O}$ ratios in silica of diatom frustules. Nature $248,40-42$.

Leng, M.J., Barker, P.A., 2006. A review of the oxygen isotope composition of lacustrine diatom silica for palaeoclimate reconstruction. Earth Sci. Rev. 75, $5-27$.

Leng, M.J., Sloane, H.J., 2008. Combined oxygen and silicon isotope analysis of biogenic silica. JQS. J. Quat. Sci. 23, 313-319.

Mackay, A.W., Karabanov, E., Leng, M.J., Sloane, H.J., Morley, D., Panizzo, V.N., Khursevich, G., Williams, D., 2008. Reconstructing hydrological variability in Lake Baikal during MIS 11; an application of oxygen isotope analysis of diatom silica. JQS. J. Quat. Sci. 23, 365-374.

Mackay, A.W., Swann, G.E.A., Brewer, T.S., Leng, M.J., Morley, D.W., Piotrowska, N., Rioual, P., White, D., 2011. A reassessment of late glacial - Holocene diatom oxygen isotope record from Lake Baikal using a geochemical mass-balance approach. JQS. J. Quat. Sci. 26, 627-634.

Meyer, H., Chapligin, B., Hoff, U., Nazarova, L., Diekmann, B., 2015. Oxygen isotope composition of diatoms as late Holocene climate proxy at two-Yurts lake, central Kamchatka, Russia. available online Glob. Planet. Change 134, 118-128. http://dx.doi.org/10.1016/j.gloplacha.2014.04.008.

Meyer, H., Schonicke, L., Wand, U., Hubberten, H.W., Friedrichsen, H., 2000. Isotope studies of hydrogen and oxygen in ground ice - experiences with the equilibration technique. Isot. Environ. Health S 36, 133-149.

Miller, G.H., Wolfe, A.P., Briner, J.P., Sauer, P.E., Nesje, A., 2005. Holocene glaciation and climate evolution of Baffin island, arctic Canada. Quat. Sci. Rev. 24, 1703-1721. http://dx.doi.org/10.1016/j.quascirev.2004.06.021.

Morley, D.W., Leng, M.J., Mackay, A.W., Sloane, H.J., Rioual, P., Battarbee, R.W., 2004. Cleaning of lake sediment samples for diatom oxygen isotope analysis. J. Paleolimnol. 31, 391-401.

Moschen, R., Lücke, A., Schleser, G.H., 2005. Sensitivity of biogenic silica oxygen isotopes to changes in surface water temperature and palaeoclimatology Geophys. Res. Lett. 32, 4.

Narancic, B., Pienitz, R., Chapligin, B., Meyer, H. and Francus, P.Postglacial environmental succession of Nettilling Lake (Baffin Island, Canadian Arctic) inferred from biogeochemical and microfossil proxies, (meant for publication within this issue as a tandem manuscript; revised version submitted after minor revisions).

Oliver, D.R., 1964. A limnological investigation of a large Arctic lake, Nettilling lake, Baffin island. Pap. Univ. Calg. 17, 69-83.

Pienitz, R., Saulnier-Talbot, É., Fallu, M.-A., Laing, T., Ponader, K., Swadling, K.E. Walker, I.R., 2004. Long-term climate stability in the Québec-Labrador (Canada) region: evidence from paleolimnological studies. In: Arctic Climate Impact Assessment (ACIA) AMAP Report, 2004, pp. 1-4.

Prest, V.K., Grant, D.R., Rampton, V.N., 1968. Geological Survey of Canada. “A” Series Map 1253A, 1 sheet. http://dx.doi.org/10.4095/108979.

Rozanski, K., Araguás-Araguás, L., Gonfiantini, R., 1993. Isotopic patterns in modern global precipitation. In: Swart, P., McKenzie, J.A., Lohmann, K.C., Savin, S. (Eds.) Climate Change in Continental Isotope Records. American Geophysical Union, pp. $1-36$

Sharp, Z.D., 1990. A laser-based microanalytical method for the in situ determination of oxygen isotope ratios of silicates and oxides. Geochim. Cosmochim. Acta $54,1353-1357$

Sharp, Z.D., Kirschner, D.L., 1994. Quartz-calcite oxygen isotope thermometry: a calibration based on natural isotopic variations. Geochim. Cosmochim. Acta 58, 4491-4501.

Shemesh, A., Charles, C.D., Fairbanks, R.G., 1992. Oxygen isotopes in biogenic silica: global changes in ocean temperature and isotopic composition. Science 256 1434-1436.

Shemesh, A., Rosqvist, G., Rietti-Shati, M., Rubensdotter, L., Bigler, C., Yam, R. Karlén, W., 2001. Holocene climatic change in Swedish Lapland inferred from an oxygen-isotope record of lacustrine biogenic silica. Holocene 11, 447-454.

Short, S.K., Mode, W.M., Davis, P.T., 1985. The Holocene record from Baffin Island: modern and fossil pollen studies. In: Andrews, J.T. (Ed.), Quaternary Environments: Eastern Canadian Arctic, Baffin Bay and Western Greenland. Allen and Unwin, Boston.

Smol, J.P., Wolfe, A.P., Birks, H.J.B., Douglas, M.S.V., Jones, V.J., Korhola, A., Pienitz, R., Rühland, K., Sorvari, S., Antoniades, D., Brooks, S.J., Fallu, M.-A., Hughes, M., Keatley, B.E., Laing, T.E., Michelutti, N., Nazarova, L., Nyman, M., Paterson, A.M. Perren, B., Quinlan, R., Rautio, M., Saulnier-Talbot, E., Siitonen, S., Solovieva, N., Weckström, J., 2005. Climate-driven regime shifts in the biological communities of arctic lakes. Proc. Natl. Acad. Sci. U. S. A. 102, 4397-4402.

Swann, G.E.A., Leng, M.J., 2009. A review of diatom $\delta^{18} \mathrm{O}$ in palaeoceanography. Quat. Sci. Rev. 28, 384-398.

Tan, F.C., Strain, P.M., 1996. Sea ice and oxygen isotopes in Foxe Basin, Hudson bay, and Hudson strait, Canada. J. Geophys. Res. 101, 20869-20876.

Thomas, E.K., Axford, Y., Briner, J.P., 2008. Rapid 20th century environmental change on northeastern Baffin Island, Arctic Canada inferred from a multi-proxy lacustrine record. J. Paleolimnol 40, 507-517. http://dx.doi.org/10.1007/s10933007-9178-y.

Thomas, E.K., Briner, J.P., Axford, Y., Francis, D.R., Miller, G.H., Walker, I.R., 2011. A 2000-yr-long multi-proxy lacustrine record from eastern Baffin Island, Arctic Canada reveals first millennium AD cold period. Quat. Res. 75, 491-500. http:// dx.doi.org/10.1016/j.yqres.2011.03.003.

Wolfe, A., 2003. Diatom community responses to late-Holocene climate variability, Baffin Island, Canada: a comparison of numerical approaches. Holocene 13 $29-37$. 